\title{
Records of ctenophores from South Africa
}

\author{
Mark John Gibbons ${ }^{\text {Corresp., }}{ }^{1}$, Steve HD Haddock ${ }^{2}$, George I Matsumoto ${ }^{2}$, Craig Foster $^{3}$ \\ ${ }^{1}$ Department of Biodiversity and Conservation Biology, University of the Western Cape, Bellville, Western Cape, South Africa \\ 2 Monterey Bay Aquarium Research Institute, Moss Landing, California, United States of America \\ 3 Sea Change Trust, Cape Town, Western Cape, South Africa \\ Corresponding Author: Mark John Gibbons \\ Email address: mgibbons@uwc.ac.za
}

Although ctenophores can be conspicuous components of the plankton in coastal marine ecosystems, only six species have been formally described from around South Africa. Using photographs from local community scientists, we add a further three species (Cestum veneris, Beroe forskalii?, Ocyropsis maculata?) and six morphospecies to the regional fauna. These additions suggest that South Africa has a ctenophore fauna that is amongst the most diverse, globally; an observation in agreement with information from other taxa. Tips on how community scientists can improve their photographic contributions to understanding ctenophore diversity are provided. 


\section{Records of ctenophores from South Africa.}

2 Mark J Gibbons ${ }^{1}$, SHD Haddock ${ }^{2}$, G I Matsumoto ${ }^{2}$ and C Foster ${ }^{3}$

3

41 University of the Western Cape, Private Bag X17, Bellville 7535, South Africa

52 Monterey Bay Aquarium Research Institute, Moss Landing, California, USA

63 Sea Change Trust, NPO Number: IT1693/2012, Unit A304, Woodstock Exchange, 66 Albert

7 Rd, Woodstock, 8001, South Africa

\section{Corresponding author}

10 All correspondence to Mark J Gibbons: mgibbons@uwc.ac.za

\section{Abstract:}

Although ctenophores can be conspicuous components of the plankton in coastal marine ecosystems, only six species have been formally described from around South Africa. Using photographs from local community scientists, we add a further three species (Cestum veneris, Beroe forskalii?, Ocyropsis maculata?) and six morphospecies to the regional fauna. These additions suggest that South Africa has a ctenophore fauna that is amongst the most diverse, globally; an observation in agreement with information from other taxa. Tips on how community scientists can improve their photographic contributions to understanding ctenophore diversity are provided.

\section{Introduction:}

The warm Agulhas Current flows southward at the edge of the narrow continental shelf along the east coast of South Africa, moving progressively offshore and westward to track the edge of the Agulhas Bank just north of East London (Lutjeharms, 2006; Figure 1). Waters of the Agulhas Current are characterised by their oligotrophic nature, and the biota is of low biomass but high diversity (Gibbons and Hutchings, 1996). At the southernmost extremity of the Agulhas Bank, the Agulhas Current retroflects eastward, shedding rings, filaments, and eddies into the South Atlantic (Lutjeharms, 2006). Upwelling along the south coast of South Africa is confined to the edge of the continental shelf and to capes and peninsulas: waters are seasonally stratified and productive, and circulation is generally sluggish (Hutchings et al., 2009). The west coast of 
32 South Africa, from the southern edge of the Agulhas Bank to the border with Namibia is bathed

33 by the cold, northward flowing Benguela Current (Hutchings et al., 2009). This area experiences

34 coastal upwelling on a seasonal basis: it is eutrophic and biological communities are

35 characterised by high biomass and low diversity (Gibbons and Hutchings, 1996).

Moving around the South African coast from east to west, there is a clear change in the physical environment and this is reflected by a change in the affinities of the marine biota, from tropical, through sub-tropical, to warm and cold temperate biogeographic provinces (Bustamente and Branch, 1996). Whilst the diversity of most marine taxa generally declines from east to west, patterns of endemism indicate that many reach a peak along the south coast (Emanuel et al., 1992; Awad et al., 2002). Especially in the case of those taxa with restricted dispersal abilities (Gibbons et al., 2010a).

Despite its relatively linear coastline of only $\sim 3700 \mathrm{~km}$, South Africa supports some of the highest levels of global marine diversity, boasting almost 13000 species (Griffiths et al., 2010). That said, our understanding of much of the region's diversity remains poorly known (Gibbons et al., 1999; Griffiths et al., 2010). One taxon that remains particularly knowledgedepauperate is the Ctenophora, despite the fact that members can be conspicuous when present (Figure 2).

Ctenophores may be found in every ocean basin of the world, from the epipelagic to the bathyal, and whilst most are planktonic others are strictly benthic. They are characterised by a body that comprises approximately $96 \%$ water and although they usually possess eight bands of cilia plates (ctene rows), these may be lost in some benthic forms. Ctenophores are predators (Haddock, 2007) and tissues will generally contain colloblasts (Leonardi, et al. in press), which are functionally equivalent to the nematocysts of Cnidaria but rather than sting they stick, ensnaring prey in a glue (von Byern et al., 2010). Some species possess tentacles with lateral tentillae at some stage in their development, whilst others do not. Almost all species are hermaphroditic (Harbison and Miller, 1986).

Ctenophores have gained significant scientific attention in recent years for two main reasons. Firstly, populations (and individuals) can grow fast, and they are known to form blooms

60 (e.g. Figure 2). Mnemiopsis leidyi, a species of pelagic lobate ctenophore naturally found along 61 the east coast of the continental United States was accidentally introduced into the Black Sea 62 during the 1980s (Shiganova, 1998). The Black Sea ecosystem at the time was not healthy; 
63 stocks of small pelagic fishes had been overexploited and there was heavy eutrophication, which, 64 when combined with a period of warm weather, led to a massive outbreak of these ctenophores 65 that served to restructure the way energy and materials flowed through the ecosystem (Kideys, 66 2002). The Black Sea system has partly recovered following the introduction of another invasive 67 ctenophore, Beroe ovata (which preys on ctenophores), whose arrival was accompanied by a decline in eutrophication and a "cold-snap" (Kideys, 2002). However, Mnemiopsis leidyi has subsequently been introduced into the Mediterranean Sea (Fuentes et al., 2009) and the Baltic Sea, the latter from a separate origin (Reusch et al., 2010).

The other reason that ctenophores have made headlines is that they may form a sister taxon to all other metazoans, being considered by some as sister to the Porifera (Dunn, et al. 2008, Shen, et al. 2017, but see Simion, 2017). Whatever their phylogenetic position, their affinities with Cnidarians are clearly convergent and not from shared ancestry (Moroz, 2015) Though nine orders, 27 families, and between 150 and 250 species are recognised at present, the higher systematics of Ctenophora is considered a mess (Giribet and Edgecombe, 2020). Part of the reason for this must undoubtedly lie with the fact that good specimens on which to base a robust phylogeny are missing. Ctenophores are very delicate animals that "disintegrate before your eyes" in most fixatives, which makes the preservation of definitive material extremely difficult. High molecular weight DNA and good quality RNA can be challenging to extract, and because of their distinct genetics, primers for amplifying standard barcoding primers like COI often fail to work when applied to ctenophores.

In their reviews of what is known about marine diversity around South Africa, Gibbons et al. (1999) and Griffiths et al. (2010) recognised eleven species of Ctenophora. These numbers were generated by our late colleague Hermes Mianzan from Mar del Plata in Argentina and 86 followed his treatment of the phylum in Boltovskoy's (1999) encyclopaedic work "Zooplankton 87 of the South Atlantic" (Mianzan, 1999). Unfortunately, the list of species that Mianzan used in 88 his contribution to Gibbons et al. (1999) has been lost, and published papers on the phylum from 89 the region are largely lacking. Indeed, with the exception of Moser's (1903) work on the 90 ctenophores collected during the Siboga Expedition, or her efforts based on the material from the 91 Deutschen Sudpolar Expedition (Moser, 1910), there are no formal descriptions of any species 92 from South Africa. References to species in regional ecological works (e.g. Gibbons et al., 1992; 
93 1999; 2002; Gibbons and Painting, 1992) are not based on definitive identifications, and caution

94 should be exercised in their too literal use beyond the level of genus.

95 In ecological studies, estimates of ctenophore abundance (counts, volume, biomass)

96 based on material that has been identified to the level of genus are unlikely to be problematic

97 owing to the fact that most members of the same genus will likely play a similar functional role

98 within the ecosystems of which they are a part. In this context, the challenge is not identifying

99 functional groups, but rather obtaining suitable quantitative samples that are in a condition to be

100 enumerated and assessed. The concept of morphospecies is therefore appropriate in such work,

101 and this lends itself to garnering the support of community science. We define a morphospecies

102 here as a morphologically distinct species, which we cannot assign to a formal description, for a

103 variety of reasons. In cases where a range-restricted species is immediately identifiable by its

104 morphology (e.g. the okapi, Okapia johnstoni), the morphospecies and the true species are the

105 same. However, in other cases, a morphospecies may comprise a number of true species that are

106 morphologically indistinguishable, or at least difficult to tell apart at a superficial level. This

107 becomes especially pertinent when the morphospecies is widely distributed. For example,

108 jellyfish of the genus Aurelia occur in many coastal regions of the world, and for decades the

109 number of taxonomically recognised species was few: almost all specimens recovered in

110 temperate boreal waters were regarded as Aurelia aurita (e.g. Kramp 1961). However, it is now

111 understood that Aurelia aurita is actually confined to NW Europe (Jarms and Morandini, 2019)

112 and that previous records in (e.g.) the Mediterranean Sea, are of other, near-cryptic species

113 (Scorrano et al. 2017). Yet from an ecological point of view it generally doesn't matter, because

114 the different true species of Aurelia within a morphospecies will likely share the majority of their

115 traits. So it is with the majority of ctenophores.

116 With the advent of digital photography and the provision of a number of online portals

117 (e.g. iNaturalist; www.inaturalist.org or Jellywatch; www.jellywatch.org) that allow image

118 sharing, reliable information on diversity is becoming increasingly part of mainstream science

119 (Silvertown, 2009). Digital cameras are becoming more affordable, and phones are ubiquitous

120 and capable of taking high-quality geolocated images. Use of these technologies by interested

121 members of the public is becoming widespread as community members share their passions for

122 the environment with others, and get feedback from experts. For large and charismatic taxa and

123 for taxa that easily identified morphologically, these images can contribute species-level 
124 information (Falk et al., 2019; Kobori et al., 2015). However, for those organisms that require

125 very detailed images taken under perfect conditions, the information that can be obtained may be

126 of value only at a higher level of identification.

127 As noted previously, morphospecies can be used to assess trends and patterns both in

128 geographic distribution and temporal cycles (but see below). Here, we aim to do two things.

129 Firstly, we use images provided by a variety of community scientists to update our knowledge of

130 ctenophores around South Africa, as Deidun (2011) did around Malta. Given what we know

131 about the diversity of other marine taxa in the coastal waters around South Africa (Griffiths et al.

132 2010), we hypothesise that taxonomic richness will be high. Secondly, owing to the generally

133 inaccessible nature of the key literature in a developing region like southern Africa, we highlight

134 important features that should allow identification of specimens in the field, and we provide

135 comments about similar species. In the hope that future photographs will be more valuable,

136 details that would permit possible identification to species level are also given, as is a brief

137 overview of ctenophore classification and anatomy.

138

139 Overview of ctenophore classification and anatomy.

140 Ctenophores either have tentacles at some stage in their life (Class Tentaculata) or they

141 lack them (Class Nuda), though it should be appreciated that many tentaculate species may lose

142 them in adulthood, or they may become very much reduced. A good source for valid ctenophore

143 species names is the web site of Mills (1998- present). The Class Nuda contains only one Order

144 (Beroida), a single Family (Beroidae) and two genera, typified by Beroe, which is the most

145 speciose. The Class Tentaculata is divided into eight orders, which can be distinguished by their

146 benthic (Platyctenida) or pelagic habit, whether they possess oral lobes (Lobata) or not, as well

147 as their general shape: approximately spherical (some Cydippida), elliptical (some Cydippida),

148 flattened (Cestidae) etc. Many of the remaining orders are either bathypelagic and thus beyond

149 the scope of community science, or are very rare and unlikely to be encountered by community

150 scientists; they are ignored here.

151 When it comes to describing ctenophores, as with all things, it is important to get your

152 bearings: what is up, what is down; what is left and what is right. This is especially important for

153 organisms like ctenophores, which show biradial symmetry. There are two "ends" to a

154 ctenophore: an oral end with a mouth and an aboral end with an often near-invisible sense organ 
155 called a statocyst. Regardless of the taxon, these "ends" can always be located in the mid-line of

156 the animal. Food is ingested via the mouth and enters a flattened pharynx (stomodaeum) where

157 digestion takes place, before being distributed through a series of canals and exiting via

158 excretory pores (also near-invisible to the naked eye). If you were to look at a ctenophore from

159 the side (aboral-end up, oral-end down), and you turn it around through $360^{\circ}$ you will have two

160 "full frontal" views of the stomodaeum (not one "front" and one "back" - remember the

161 rotational symmetry), and two "side-on" views (Figure 3). Note that these views do not have

162 exact bilateral or mirror symmetry, meaning that the left half of a front view may be slightly

163 different than the right half. When you view an oral or aboral image of a ctenophore you can see

164 both the stomodaeal (or pharyngeal) plane of view (blue line in Figure 3b) and the tentacular

165 plane of view (yellow line in Figure 3b). This "top-down" perspective is also where the subtle

166 asymmetries are most apparent, in the path connecting to the anal pores.

167 Pelagic ctenophores will have eight rows of symmetrically arranged cilia plates that are

168 used for locomotion and, with the exception of beroids and adult Ocyropsis, two tentacles of

169 variable length and arrangement (Figure 4). The four ctene rows adjacent to the stomodaeum and

170 the stomodaeal plane are referred to as sub-stomodaeal, whilst those adjacent to the tentacles and

171 the tentacular plane are known as sub-tentacular - and the two sets may be of different lengths.

172 The numbers of cilia per plate and the number and spacing of plates per row can be important

173 features at the species-level. A pair of extensible tentacles retract to a bulb, and emerge from the

174 body of Cydippida via tentacular sheaths (Figure 4a). Where the tentacles emerge along the body

175 is important for identification purposes, as too is information on the relative size and internal

176 orientation of the sheaths. Most tentacles are deployed angled away from the mouth, but in a few

177 genera (Lampea, Dryodora) they may emerge laterally, or even be orally directed as in

178 Haeckelia. Tentacles may possess side branches called tentilla; or they may not: this is also

179 important for identification. On these tentilla are the specialized colloblasts, which aid in prey

180 capture.

181 Lobate ctenophores possess two cup-shaped oral lobes that are obvious viewed from the

182 stomodeal plane, and four auricles (Figure 4B). The relative shape, size and thickness of the

183 lobes are important features for identification purposes, as too is the arrangement of the various

184 canals that run through the tissue. External papillae may occur in some taxa. The relative length

185 of the auricles, which are situated at the base of the lobes near the mouth, varies between taxa; 
186 they may be coiled (or not) and slender (or not) and have ciliated edges. It should be realized that

187 juvenile lobate ctenophores possess long tentacles and lack obvious lobes, and that they resemble 188 cydippids.

189 Although pelagic ctenophores are generally translucent, they may possess pigment spots 190 and can be bioluminescent. The latter is challenging to video or photograph, but should be noted.

\section{Taking pictures of ctenophores in situ}

The vast majority of recreational divers and underwater photographers (community

194 scientists) rarely have the time, tools, facilities, or collecting permits to capture animals,

195 transport them to an aquarium and photograph them ex situ. Consequently, we do not summarise

196 the methods that would be used to take such images here, and the interested reader is referred to

197 the internet where a number of resources about aquarium photography can be found (e.g.

198 Haddock, 2011).

All of the images used here were captured in situ. Good pictures require sunny conditions or the use of lights. The subject should ideally be backlit by the sun, and the background should be dark. It often helps to underexpose by up to two stops to bring out details and not to overexpose bright areas. Be cautious not to swirl water near animal or disturb its rhythm. Try to photograph the animal from six different angles to get all sides of it. It can be useful to do a few shots directly as well as from below for a different kind of translucent detail. Avoid blurring by keeping the camera still and gently depressing trigger. Take many pictures and edit the clearest ones. Take wide-angle, close ups, and macro shots if possible. Relax the hands and body while working. Animals near the surface will normally have better light. Use backlighting with a separate light if animals are deeper.

\section{The images}

211 Although iNaturalist represents an extremely valuable resource for studying morphospecies, and

212 we encourage all interested community scientists to upload their images there or to another

213 similarly organised platform, the coverage of ctenophores is incomplete. At the time of writing,

214 there are a total of sixteen ctenophore records on iNaturalist for South Africa, which is clearly

215 not enough to report on regional biodiversity! As a consequence, a personal request was made to

216 the network of known underwater photographers in the region for them to dig deep into their 
217 archives and send through any captured images. The photographs used here, therefore, do not

218 represent the total population of possible images but simply those from the sampled

219 photographers. Full details of contributors can be found in the acknowledgements and, where

220 appropriate, in the Figure legends. With the exception of the images of Lyrocteis sp., all the

221 photographs shown here were collected by divers using SCUBA or snorkel gear with a variety of

222 underwater cameras. Some of the pictures were taken in water with a depth shallower than $3 \mathrm{~m}$,

223 whilst others were "snapped" during decompression stops after deep dives: all were taken close

224 to the surface.

225

226 The morphospecies

227 Tentaculata

228

\section{Cydippida}

229

Hormiphora sp. Morphospecies. Pelagic. Body a prolate spheroid, slightly broader at oral end, may be moderately compressed in the tentacular plane, up to $30 \mathrm{~mm}$ in length, transparent; tentacle bulbs in close proximity to stomodeum, between 25 - 50\% stomodeum length; tentacle sheaths parallel stomodeum for some distance; stomodeum greater than 50\% body length; all eight ctene rows approximately equal in length, extend greater than $75 \%$ of body length from aboral end. Seventeen species recognised globally, and although none have formally been described from South Africa it is known to occur from northern KwaZulu Natal to the SW Cape (Figure 5a, c). Good pictures require a focus on the length and position of the tentacle bulbs relative to the stomodaeum, where the tentacle exits the body, detail of tentacle and any unusual shape to the tentilla (coiled, "hand-shaped", globular), as well as the overall body shape.

Pleurobrachia sp. Morphospecies. Pelagic. Body approximately spherical, less than 20 $\mathrm{mm}$ in diameter, transparent; tentacles emerging close to aboral end, tentacle bulbs short, less than $25 \%$ stomodeum (stomodaeum) length; tentacle sheaths orientated at pronounced angle from stomodeum; stomodeum less than half body length. All eight ctene rows approximately equal in length, extend $75 \%$ of body length from aboral end. Ten species recognised globally, two of which have been described from South Africa: Pleurobrachia pileus from the west coast and $P$. pigmentata from Durban (Moser 1903, 1910). Characters that can be used to distinguish between these two species include, in the case of $P$. pigmentata, pigmentation along the ctene 
248 rows, very wide dense ctene rows, and what is described as a constriction of the oral third of the

249 body. A shallow water taxon, species of Pleurobrachia (sea-gooseberry) may be common in

250 harbours and enclosed embayments around the coast (Figure 5b, d). Good pictures require a

251 focus on the origin and angle of the tentacular sheaths relative to the stomodeum, the relative

252 lengths of the ctene rows and the density of ctenes. It should be stressed that many tentaculate

253 ctenophores have larvae that resemble Pleurobrachia, so caution should be exercised in putting

254 names to small cydippids.

255

256

Callianira antarctica. Species. Pelagic. Although generally regarded as a polar species,

257

Moser (1910) collected two specimens in oceanic waters NW of Cape Town at a temperature of

258

$14.6^{\circ} \mathrm{C}$. Body strongly compressed in the stomodaeal plane, ovoid but with two aborally

259

projecting wing-shaped keels, giving it an arrowhead shape; transparent; to $16 \mathrm{~cm}$. Tentacles

260

emerge, and all ctene rows end, at base of keels. Sub-stomodeal ctene rows slightly longer than

261

sub-tentacular ones. Unlikely to be seen close to continental South Africa. Not illustrated.

262

263

\section{Cestida}

264

265

Cestum veneris. Species. Pelagic. Body laterally expanded and flattened, long and ribbon-like, up to $1.5 \mathrm{~m}$ in "length" (=width), transparent. Tentacles fringe the mouth opening, which extends along the "length" of oral surface, with tentilla forming a veil across body. Four (sub-stomodaeal) ctene rows run along "length" of aboral surface, two each side; four short subtentacular ctene rows around sense organ. "The set of canals that run along the middle of the body originate near the base of the stomodeum, rapidly curving up to the midline" (Mills and Haddock, 2007). In other words, if you trace the canal funning along the midline from a "wingtip" toward the center of the body, it will make an S-shaped digression before joining the canals at the center of the body. Contrast this with Velamen parallelum, whose canals continue straight from the tip to their point of intersection. Velamen does not reach the sizes of Cestum, but it may be hard to distinguish small specimens. Other keys to look for are the Cestum may have purplish-black pigment on its wingtips, and the gonads of Velamen form a frosty-looking dashed line vs. a continuous line in Cestum; Cestum can also roll itself up while Velamen cannot. Both species are monotypic and occur worldwide in tropical and subtropical regions, moving 
279 Velamen). Recorded around South Africa from southern Mozambique to False Bay, Cape Town

280 (Figure 6). Distinguishing the two species requires good photographs of the stomodaeal region to

281 highlight the presence/absence of sub-tentacular ctene rows and the origins of the lateral canals.

282

283

Lobata

284

Ocyropsis sp. Morphospecies, but see below. Pelagic. Body resembles "the general shape 285 of two hands held together in prayer" (Gershwin et al., 2010), characterised by the presence of

286

287

288

289

290

291

292

293

294

295

296

297

298

299

300

301

302

303

304

305

306

307

308

309 two large, lateral muscular lobes that extend well beyond the mouth; generally less than $5 \mathrm{~cm}$ in "length"; pale and translucent, lobes sometimes bearing black or brown pigment spots. Although the latter feature is diagnostic for Ocyropsis maculata (arrow in Figure 7b), we need to remember that incomplete global sampling means that local specimens may yet be distinct (hence our use of "?"). The shape of the stomodeum is an important diagnostic feature, as too is the origin of the different ctene rows: sub-tentacular ctene rows shorter than sub-stomodaeal ctene rows, former extending to base of lobes, latter to a variable distance along lobes. Tentacles reduced or absent in adults; with four auricles of variable shape and length (arrow in Figure 7a), usually appear as a narrow triangle. Although five species are recognised globally from both warm and cold temperate oceans, none have been formally described from South Africa though photographs indicate it occurs in the region from southern Mozambique to False Bay (Figure 7). Swimming behaviour (a series of 'claps') is diagnostic. The species can be separated with some difficulty and good pictures require a focus on the ctene rows, stomodaeum, any tentacular apparatus as well as pigmentation (or lack of) on lobes.

Bolinopsis sp. Morphospecies. Pelagic. Body egg-shaped, slightly broader at oral end; less than $10 \mathrm{~cm}$ in length (including lobes); transparent. Two lobes of variable conspicuity arise between mouth and statocyst to surround and extend beyond mouth a variable distance. Four sub-stomodaeal ctene rows extend a variable distance along lobes from aboral pole, whilst each sub-tentacular row generally terminates at an auricle. Auricles narrow and ribbon-like, reaching to a variable distance beyond mouth. With two short tentacles arising adjacent to, and fringing, oral surface. Ten species recognised globally, and although none have formally been described from the region, it has been photographed around South Africa and appears to extend from southern Mozambique to False Bay (Figure 8). Some species of Bolinopsis are strongly 
310 pigmented, others may bear tubercles on outer surface; the arrangement of the canals in the lobes

311 is diagnostic. Good pictures require a focus on the point of connection from the lobes to the body

312 (whether near the level of the mouth or closer to the statocyst) and the shape of the auricles.

313

314

Leucothea sp. Morphospecies. Pelagic. Body approximately oblong, compressed, with

315 numerous tubercles on outer surface; to a length of approximately $20 \mathrm{~cm}$; often lightly

316 pigmented, transparent. Two prominent lobes arise near the level of the mouth to surround and

317 extend beyond mouth a variable distance. (Lobes coil and change disposition when disturbed.)

318 Aboral end markedly indented. Four sub-stomodaeal ctene rows extend a variable distance along

319 lobes from aboral pole, whilst each sub-tentacular row generally terminates close to the origin of

320 the auricle. Auricles cylindrical or ribbon-like, often coiled, and elongated relative to other

321 lobates. Two long, trailing tentacles arising adjacent to mouth. Seven species recognised globally

322 from tropical and subtropical waters, which can be differentiated by the arrangement of the

323 canals in the lobes, and the nature of papillae, including the presence of orange pigmentation.

324 Species belonging to this genus have been photographed in the region from southern

325 Mozambique to False Bay (Figure 9). Good pictures require a focus on the body texture and

326 papillae, the origin of the lobes, and the auricles

327

328

Eurhamphaea sp. Morphospecies. Pelagic. Body narrow, compressed in stomodaeal

329 plane, with two relatively firm gelatinous projections aborally that each terminate in a simple

330 filament of variable length to give the animal a pointed, angular appearance; to $10 \mathrm{~cm}$ in length,

331 more commonly $<5 \mathrm{~cm}$; transparent, with conspicuous red "spots" even as juveniles. Spots may

332 disappear if the organism is disturbed and releases its yellow ink. Statocyst sunk in a deep cleft.

333 With two relatively short lobes and stiff, narrow auricles. Four sub-tentacular ctene rows extend

334 along length of aboral projections; four sub-stomodaeal ctene rows arise at edge of aboral cleft

335 and extend orally to base of lobes. Five species are recognised globally, all of which were first

336 described during the early 1800 s, but the genus is functionally monospecific, with few records of

337 all but Eurhamphaea vexilligera. Photographed in the region only from southern Mozambique

338 (Figure 10).

339

\section{Platyctenida}


342 living flatworm; variously coloured, often brightly but may also be cryptic; rarely more than 30

$343 \mathrm{~mm}$ in length. With two, long finely branched tentacles that arise from "chimneys" at variable

344 positions on body. Body surface may have variable numbers of extendable papillae, arranged in

345 variable ways. Lacking ctene rows. Thirty-two species recognised globally; none formally

346 described from South Africa but specimens have been photographed in both southern

347 Mozambique and False Bay (Figure 11). Very difficult to identify from photographs alone,

348 requiring a focus on coloration and the number and distribution of papillae. They tend to have

349 close associations with other benthic organisms, and the identify of their "host" can assist in

350 identification (e.g. Matsumoto, 1999).

351

352

Lyrocteis sp. Morphospecies. Benthic. Body erect and "lyre-shaped"; sessile; maybe

353 brightly coloured; to a height of $15 \mathrm{~cm}$. Ctenes absent in the adult; a tentacle arises from a furrow at the tip of each aboral arm, tentillae arising on one side only. Arms may (L. imperator), or may not (L. flavopallidus), have longitudinal ridges on outer margin; trunk and proximal part of arms may bear numerous small papillae (L. imperator). Two species recognised globally from Japan (L. imperator) and Antarctica (L. flavopallidus). Recorded locally only in the deep canyons off northern KwaZulu Natal (Figure 12). Note the variety of colours shown by the specimens photographed, which, given that colour tends to be unique to species of Coeloplana, means it is possible that more than one species may be present.

361

362

363

364

365

366

367

368

369

370

371

Nuda

\section{Beroida}

Beroe sp. Morphospecies but see below. Pelagic. Body cylindrical and cigar-shaped, variously flattened; opaque, to a maximum of $20 \mathrm{~cm}$. Without tentacles. With eight ctene rows, of variable length. Twenty-six species recognised globally from all oceans and seas, and three species have been formally described from South Africa (Beroe cucumis, Beroe hyalina, Beroe (Pandora) mitrata) according to Moser (1910). Here we add another potential species to the regional fauna, Beroe forskalii? (Figure 13d), which can be identified by its conical shape and generally pinkish hue. The different species of Beroe can be differentiated by their shape, the 
372 relative lengths of the ctene rows and the arrangement and level of anastomoses of the different

373 canals (Figure 13c). In B. forskalii, side branches arising from the canals connect into a fully

374 connected mesh (anastomose). In other species, the side branches may divide multiple time, but

375 they terminate blindly. Good pictures require a focus on body shape, coloration if any, canal

376 structure within body and the shape and form of the oral end of the body. Probably the most

377 common morphospecies of ctenophore recorded in the region, which can be found around the

378 coast from southern Mozambique to the Orange River.

379

380 Comments

381 As noted earlier, six species of ctenophore have formally been documented and described

382 from around South Africa (Pleurobrachia pileus, P. pigmentata, Callianira antarctica, Beroe

383 cucumis, B. hyalina, B. mitrata), and we have updated that list here to include a further three

384 (potentially) full species (Cestum veneris, Beroe forskalii?, Ocyropsis maculata?) and six

385 morphospecies (Hormiphora sp., Leucothea sp., Bolinopsis sp., Eurhamphaea sp., Coeloplana

386 sp., Lyrocteis sp.). Because most of the effort is focused on the nearshore environment, for

387 obvious reasons, the species observed are those with an affinity for such environments - hence,

388 with the exception of Lyrocteis, the absence of deeper water forms. The images of Lyrocteis

389 shown here were collected from about $70 \mathrm{~m}$ depth using a remotely operated vehicle as part of

390 ongoing investigations into the ecosystem occupied by the coelacanth Latimeria chalumnae.

391 The genera observed have widespread distributions in coastal areas (Table 1) and have

392 been recorded off Australia (Gershwin et al., 2010), in the Mediterranean Sea (Madin 1991;

393 Shiganova and Malej 2009; Deidun 2011; Cinar et al., 2014), in the NW (Mayer 1912) and NE

394 Atlantic (Moro et al. 2013), around South America (de Oliviera et al. 2007, 2016; Schiariti et al.

395 2020) and along the Pacific coast of North America (Wrobel and Mills, 1998; Mills and

396 Haddock, 2007; Ruiz-Escobar et al., 2015). The taxa that would appear to be missing from

397 regional waters include species of Lampea as well as Deiopea kaloktenota and Velamen

398 parallelum, all of which are commonly reported from temperate and subtropical coastal

399 environments elsewhere. Species of Lampea resemble those of the common cydippid

400 Pleurobrachia, but have an avocado or bottle shape, not ovoid, with the body being drawn out

401 orally; the ctene rows only extend to about half the body length and individuals have a large

402 stomodeum. Species in this genus consume salps (Harbison et al., 1978), and given that large 
403 blooms of these can be encountered over the Agulhas Bank (de Decker, 1973) it is likely that 404 Lampea is present in the region. Like species of Lampea, Deiopea kaloktenota rarely grows to 405 more than $5 \mathrm{~cm}$ in size: it is very transparent, has short lobes and has widely spaced ctenes on the 406 ctene rows. Small size and fragility characterises the species that have not been recorded locally, 407 which would agree with other community science-based efforts to map ctenophore diversity (e.g. 408 Deidun, 2011).

409 Given South Africa's geographic position between the Indian and Atlantic oceans, and 410 the strong nature of the Agulhas Current (Lutjeharms, 2006), the number of ctenophore species 411 that can be expected is certain to be much higher than presently noted. Regional waters support 412 between (approximately) 40-56\% of the global holoplanktonic hydrozoan fauna (Gibbons et al., 413 2010a) and $57 \%$ of the world's euphausiids (Gibbons et al., 1995), the latter being an

414 holoplanktonic group of crustaceans. Whilst the majority of ctenophores are holoplanktonic and 415 show limited endemism (but see Geshwin et al., 2010), some are benthic, and it is entirely likely 416 that endemic species will be found amongst the Platyctenida. Gibbons et al. (2010b) noted that 417 within Hydrozoa, those genera showing restricted patterns of dispersal tended to be more diverse 418 than those with a relatively long-lived medusa phase. It comes as no surprise then that the two 419 most specious ctenophore genera (Coeloplana and Ctenoplana) display similarly restricted 420 patterns of dispersal.

Although a lesser number of ctenophores has been noted from around South Africa than

422 Australia (Gershwin et al., 2010; Table 1), the length of the regional coastline is only about 3700

$423 \mathrm{~km}$. The latter distance equates to about $50 \%$ of that of Brazil, which boasts 13 species: not 424 morphospecies (Oliveira et al., 2016). Consequently, the diversity of ctenophores in the region 425 must be regarded as comparatively high, especially given that there are no locally situated 426 ctenophore taxonomists, like there are in North America (e.g. Mills and Haddock, 2007) or 427 Brazil (e.g. Oliveira et al., 2016), and as there were in Australia (e.g. Matsumoto and Gowlett428 Holmes, 1996; Gershwin et al., 2010). In these other environments, many species have only been 429 observed through specialised and dedicated methods, such as submersibles and blue-water scuba 430 diving, so additional diversity is sure to be uncovered over time. As has been suggested for other 431 taxa, the high diversity noted in the region must be attributable to the diversity of water masses 432 and environments that occur. Environments that span the gamut from coral reefs in the extreme 
$433 \mathrm{NE}$ of the country, which experience water temperatures in the upper $20 \mathrm{~s}$, to less than $8^{\circ} \mathrm{C}$ noted 434 in the kelp beds along the west coast (Griffiths et al., 2010).

435 The images shown here were solicited from the community scientists listed in the 436 acknowledgements below. They represent the clearest, most unambiguous photographs reviewed 437 and are the ones that we consider to be most suitable for illustrating the species recorded. It 438 should be stressed, however, that these images were in the minority, and the vast majority of 439 pictures were either snapped in turbid waters when animals were partially obscured by bubbles 440 or detritus, or the specimen was moving and the images were slightly blurred and out of focus. A 441 professional photographer, or even a selective amateur, is likely to quickly consign such images 442 to "trash" - writing them off as embarrassing mistakes. But regardless of how embarrassing they 443 may seem to the photographer, these pictures can still be valuable to science if the specimens 444 they portray can be identified to morphospecies. Remember, mapping diversity is one thing, but 445 platforms such as iNaturalist also allow us to understand ecological and environmental change, 446 IF they are used by community scientists on a routine and ongoing basis. We illustrate what we 447 mean, using the photographs taken by Peter Southwood.

$448 \quad$ Peter is a retired engineer, and he has been taking underwater photographs in False Bay 449 since 2003. He usually dives at least once every weekend when he is at home, and he has 450 captured more than 120000 digital images $(508 \mathrm{~GB})$ of marine animals that span the taxonomic 451 gamut from sponges to dolphins. Table 2 displays the number of dives in which Peter has 452 photographed ctenophores, by month over the period $2003-2019(\mathrm{n}=711)$. These data suggest 453 that, in False Bay, ctenophores are relatively uncommon and are seen only on about $11 \%$ of trips. 454 Beroe can be found throughout the year, Leucothea is present from May to September, whilst 455 Ocyropsis is only seen between April and June. These observations may be real and may impart 456 real information about seasonal changes in distribution that we could try and relate to seasonal 457 changes in the oceanographic environment within False Bay. However, they are also biased and 458 will reflect Peter's willingness to hold on to poor images, his willingness to take a photograph of 459 "yet another ctenophore" when the visibility is poor and he is running out of air. Consequently, 460 scientists must be careful when they try and use such data in this way, unless community 461 scientists routinely capture and share their photographs. It is a "numbers game": the more data 462 collectors there are, the greater the chances that images not taken by Peter on any given day, will 463 be captured by someone else. 


\section{Acknowledgements}

466 We dedicate this paper to all the different local community scientists that have contributed 467 photographs for this project (Peter Southwood, Georgina Jones, Geoff Spiby, Mike and Val 468 Fraser, Dennis King, Louis van Wyk, Jenny Stromvoll, Guido Zsilavecz), and we urge them to 469 keep up their excellent efforts and to spread the word: all the photographs used here remain their 470 property. Community science platforms such as iNaturalist (www.inaturalist.org) and Jellywatch 471 (www.jellywatch.org) are to be applauded for the work they do, and we encourage all interested 472 persons who have taken photographs of ctenophores, however embarrassing they may seem to 473 you personally, to upload them to the iNaturalist site so we can push this and other biodiversity 474 projects forwards. It should be remembered that verified photographs are used by the AI 475 algorithms in iNaturalist to assist community members in the identification of posted specimens. 476 Thanks to Cathy Boucher for assistance with the preparation of the figures. This manuscript has 477 benefited from the comments supplied by our colleague Larry Madin and another "anonymous" 478 reviewer, and we are grateful for their efforts in this regard.

479

480 References

481 Alamaru A, Brokovich E, Loya Y. Four new species and three new records of benthic 482 ctenophores (Family: Coeloplanidae) from the Red Sea. Mar Biodiv. 2015;DOI $10.1007 / \mathrm{s} 12526-015-0362-4$

Awad AA, Griffiths CL, Turpie JK. Distribution of South African marine benthic invertebrates applied to the selection of priority conservation areas. Div Distr. 2002;8:129-145.

Boltovskoy D. South Atlantic Zooplankton. Backhuys Publishers. 1999

Buecher E, Gibbons MJ. Interannual variation in the composition of the assemblages of medusae and ctenophores in St Helena Bay, Southern Benguela Ecosystem. Sci Mar. 2000;64, supplement1:123-134.

Bustamante RH, Branch GM. Large scale patterns and trophic structure of southern African rocky shores: the roles of geographic variation and wave exposure. J Biogeog. 1996;23:339-351.

Çinar ME, Yokeş MB, Açik S, Bakir AK. Checklist of Cnidaria and Ctenophora from the coasts of Turkey. Turk J Zool. 2014;38:677-697. 
495 De Decker AHB. Agulhas Bank plankton. In The biology of the Indian Ocean (ed. B.

496 Zeitzschel), pp. 189-219. Berlin: Springer Verlag. 1973

497 Deidun A. A collection of recent ctenophore sightings from the Maltese Islands. J Black

$498 \quad$ Sea/Med Env. 2011;17:4-13.

499 Dunn CW, Hejnol A, Matus DQ, Pang K, Browne WE, Smith SA, Seaver E, Rouse GW, Obst

500 M, Edgecombe GD, Sørensen MV, Haddock SHD, Schmidt-Rhaesa A, Okusu A,

501 Kristensen RM, Wheeler WC, Martindale MQ, Giribet G. Broad phylogenomic sampling

502 improves resolution of the animal tree of life. Nature 2008;452:745-749

503 Dunn CW, Leys SP, Haddock SHD. The hidden biology of sponges and ctenophores. Trends

$504 \quad$ Ecol Evol. 2015;30:282-291.

505 Emanuel BP, Bustamente RH, Branch GM, Eekhout S, Odendaal FJ. A zoogeographic and

506 functional approach to the selection of marine reserves on the west coast of South Africa.

507 S Afr J Mar Sci. 1992;12:341-354.

508 Falk S, Foster G, Comont R, Conroy J, Bostock H, Salisbury A, Kilbey D, Bennett J, Smith B. Evaluating the ability of citizen scientists to identify bumblebee (Bombus) species. PLoS ONE 2019;14(6):e0218614. https://doi.org/10.1371/journal.pone.0218614

511 Fuentes VL, Atienza D, Gili J-M, Purcell JE. First records of Mnemiopsis leidyi A. Agassiz 1865 off the NW Mediterranean coast of Spain. Aquatic Invasions. 2009;4:671-674.

513 Gershwin L, Zeidler W, Davie PJF. Ctenophora of Australia. In, Davie PJF, Phillips JA (Eds), Proceedings of the Thirteenth International Marine Biological Workshop, the Marine Fauna and Flora of Moreton Bay, Queensland. Mem Queensland Mus. 2010;54:1-45.

Gibbons MJ, Abiahy BB, Angel M, Assuncao CML, Bartsch I, Best P, Biseswar R, Bouillon J, Bradford-Grieve JM, Branch W, Burreson E, Cannon L, Casanova J-P, Channing A, Child CA, Compagno L, Cornelius PFS Dadon J R, David JHM, Day J, Della Croce N, Emschermann P, Erseus C, Esnal G, Gibson R, Griffiths CL, Hayward PJ, Heard R, Heemstra P, Herbert D, Hessler R, Higgins R, Hiller N, Hirano YM, Kensley B, Kilburn R, Kornicker L, Lambshead J, Manning R, Marshall D, Mianzan H, Monniot C, Monniot F, Newman W, Nielsen C, Patterson G, Pugh P, Roeleveld M, Ross A, Ryan P, Ryland JS, Samaai T, Schleyer M, Schockaert E, Seapy R, Shiel R, Sluys R, Southward EC, Sulaiman A, Thandar A, van der Land J, van der Spoel S, van Soest R, Vetter E, 
525

526

527

528

529

530

531

532

533

534

535

536

537

538

539

540

541

542

543

544

545

546

547

548

549

550

551

552

553

554

555

Vinogradov G, Williams G, Wooldridge T. The taxonomic richness of South Africa's marine fauna: a crisis at hand. S Afr J Sci. 1999;95:8-12.

Gibbons MJ, Buecher E, Thibault-Botha D, Helm RR. Patterns in marine hydrozoan richness and biogeography around southern Africa: implications of life-history strategy. J Biogeog. 2010a;37:606-616.

Gibbons MJ, Buecher E, Thibault-Botha D. Observations on the ecology of Pleurobrachia pileus (Ctenophora) in the southern Benguela ecosystem. S Afr J Mar Sci. 2003;25:253-261.

Gibbons MJ, Buecher E. Short-term variability in the assemblage of medusae and ctenophores following upwelling events in the southern Benguela ecosystem. Mar Ecol Prog Ser. 2001;220:169-177.

Gibbons MJ, Gugushe N, Boyd AJ, Shannon LJ, Mitchell-Innes BA. Changes in the composition of the non-copepod zooplankton assemblage in St Helena Bay (southern Benguela ecosystem) during a six-day drogue study. Mar Ecol Prog Ser. 1999;80:111-120

Gibbons MJ, Hutchings L. Zooplankton diversity and community structure around southern Africa, with special attention to the Benguela upwelling system. S Afr J Sci. 1996;92:6376.

Gibbons MJ, Janson LA, Ismail A, Samaai T. Life-cycle strategy, species richness and distribution in marine Hydrozoa (Cnidaria: Medusozoa). J Biogeog. 2010b;37:441-448.

Gibbons MJ, Painting SJ. The effects and implications of container volume on clearance rates of the ambush entangling predator, Pleurobrachia pileus (Ctenophora, Tentaculata). J Exp Mar Biol Ecol. 2001;163:199-208.

Gibbons MJ, Stuart V, Verheye HM. Trophic ecology of carnivorous zooplankton in the Benguela. S Afr J Mar Sci, 1992;12:421-437.

Giribet G, Edgecombe GD. The Invertebrate Tree of Life. Princeton University Press, New Jersey, 2020.

Griffiths CL, Robinson TB, Lange L, Mead A. Marine Biodiversity in South Africa: An Evaluation of Current States of Knowledge. PLoS ONE 2010;5(8):e12008.

Haddock, SHD. Photographing your jellyfish. Make Magazine. 2011;27:91 https://books.google.com/books?id=xfax4r5mfdsC\&pg=PA91

Haddock SHD. Comparative feeding behavior of planktonic ctenophores. Integr Comp Biol. 2007;47:847-853. 
556 Harbison GR, Madin LP, Swanberg NR. On the natural history and distribution of oceanic

557

558

559

560

561

562

563

564

565

566

567

568

569

570

571

572

573

574

575

576

577

578

579

580

581

582

583

584

585 ctenophores. Deep-Sea Res. 1978;25:233-56.

Harbison GR, Miller RL. Not all ctenophores are hermaphrodites. Studies on the systematics, distribution, sexuality and development of two species of Ocyropsis. Mar Biol. 1986;90:413-424.

Hutchings L, van der Lingen CD, Shannon LJ, Crawford RJM, Verheye HMS, Bartholomae CH, van der Plas AK, Louw D, Kreiner A, Ostrowski M, Fidel Q, Barlow RG, Lamont T, Coetzee J, Shillington F, Veitch J, Currie JC, Monteiro PMS. The Benguela Current: An ecosystem of four components. Prog Oceanogr. 2009;83:15-32

Jarms G, Morandini AG. World Atlas of Jellyfish. Dölling und Galitz Verlag, Hamburg. 2019

Javidpour J, Sommer U, Shiganova T. First record of Mnemiopsis leidyi A. Agassiz 1865 in the Baltic Sea. Aquatic Invasions 2006;1:299-302.

Kideys AE. Fall and rise of the Black Sea eco -system. Science 2002;297:1482-1484.

Kobori H, Dickinson JL, Washitani I, Sakurai R, Amano T, Komatsu N, Kitamura W, Takagawa S, Koyama K, Ogawara T, Miller-Rushing AJ. Citizen science: a new approach to advance ecology, education, and conservation. Ecol Res. 2016;31:1-19

Kramp PL. Synopsis of the medusae of the world. J Mar Biol Assoc UK. 1961;40:1-469

Leonardi ND, Thuesen EV, Haddock SHD. (in press) A sticky thicket of glue cells: an ultrastructural study of colloblasts in twenty species of comb jelly (phylum Ctenophora). Ciencias Marinas.

Lutjeharms JRE. The Agulhas Current. Springer. 2006

Madin LP. Distribution and taxonomy of zooplankton in the Alboran Sea and adjacent western Mediterranean: a literature survey and field guide. Woods Hole Oceanogr Instit. 1991;1147

Matsumoto GI, Gowlett-Holmes KL. Coeloplana scaberiae sp. nov., a new benthic ctenophore (Ctenophora: Platyctenida: Coeloplanidae) from South Australia. Rec S Austr Mus. 1996;29:33-40.

Matsumoto GI. A new species of lobate ctenophore, Leucothea pulchra sp. nov., from the California Bight. J Plankt Res. 1988;10:301-311.

Matthews DC. Records of Hawaiian Ctenophora. Trans Am Microsc Soc. 1954;73:282-284. 
586 Mayer AG. Ctenophores of the Atlantic Coast of North America. Carnegie Institution of

587

588

589

590

591

592

593

594

595

596

597

598

599

600

601

602

603

604

605

606

607

608

609

610

611

612

613

614

615

616 Washington, Washington, 2012;1-58

Mianzan HW. Ctenophora. In: Boltovskoy D, (Ed.), South Atlantic Zooplankton. Backhuys Publishers. 1999;561-573

Mills, C.E. Internet 1998-present. Phylum Ctenophora: list of all valid species names. Electronic internet document available at http://faculty.washington.edu/cemills/Ctenolist.html. Published by the author, web page established March 1998, last updated 2017.

Mills CE, Haddock SHD. Ctenophores. In: Carlton JT. (Ed.), Light and Smith's Manual: Intertidal Invertebrates of the Central California Coast. 4th Edition. University of California Press, Berkeley, 2007;189-199.

Moro L, Boelkhe V, Escatllar J, Bacallado JJ. Nota sobre la presencia de Ocyropsis crystallina (Rang, 1828) (Ctenophora: Lobata) en las Islas Canarias. Rev Acad Canar Cienc. 2013;25:129-133.

Moroz LL. Convergent evolution of neural systems in ctenophores. J Exp Biol. 2015;218:598611.

Moser F. Die Ctenophoren der Siboga-Expedition. EJ Brill, Leiden, 1903;1-34

Moser F. Die Ctenophoren der Deutschen Südpolar-Expedition 1901-1903. Deutsche SüdpolarExpedition, 1910;11:117-192.

Oliveira OMP, Araújo EM, Ayón P, Cedeño-Posso CM, Cepeda AA, Córdova P, Cunha AF, Genzano GN, Haddad MA, Mianzan HW, Migotto AE, Miranda LS, Morandini AC, Nagata RM, Nascimento KB, Nogueira M, Palma S, Quiñones J, Rodriguez CS, Scarabino F, Schiariti A, Stampar SN, Tronolone VB, Marques AC. Census of Cnidaria (Medusozoa) and Ctenophora from South American marine waters. Zootaxa 2016;4194:1-256.

Oliveira OMP, Mianzan H, Migotto AE, Marques AC. Identification key for the ctenophores from Brazilian coast. Biota Neotropica. 2006;7:341-350

O'Sullivan D. A guide to the ctenophores of the Southern Ocean and adjacent waters. ANARE Res Notes 1986;36:1-43.

Reusch TBH, Bolte SR, Sparwel M, Moss AG, Javidpour J. Microsatellites reveal origin and genetic diversity of Eurasian invasions by one of the world's most notorious marine invader, Mnemiopsis leidyi (Ctenophora). Mol Ecol. 2010;19:2690-2699 
617 Robilliard GA, Dayton PK. A new species of platyctenean ctenophore, Lyrocteis flavopallidus

618

619

620

621

622

623

624

625

626

627

628

629

630

631

632

633

634

635

636

637

638

639

640

641

642

643

644

645

646

647

sp. nov., from McMurdo Sound, Antarctica. Can J Zool. 1972;50:47-52.

Ruiz-Escobar F, Valadez-Vargas DK, Oliveira OMP. Ctenophores from the Oaxaca coast, including a checklist of species from the Pacific coast of Mexico. Zootaxa 2015;3936:435-445

Schiariti A, Dutto MS, Oliveira OM, Siquier GF, Tapia FAP, Chiaverano L. Overview of the comb jellies (Ctenophora) from the South-western Atlantic and Sub Antarctic region (32$\left.60^{\circ} \mathrm{S} ; 34-70^{\circ} \mathrm{W}\right), \mathrm{N} Z \mathrm{~J}$ Mar Freshwater Res, 2020; https://doi.org/10.1080/00288330.2020.1775660

Scorrano, S., Aglieri, G., Boero, F., Dawson, M.N. \& Piraino, S. Unmasking Aurelia species in the Mediterranean Sea: an integrative morphometric and molecular approach. Zool J Linn Soc. $2017 ; 180: 243-267$.

Shen X-X, Hittinger CT, Rokas A. Contentious relationships in phylogenomic studies can be driven by a handful of genes Nat Ecol Evol. 2017;1:126

Silvertown J. A new dawn for citizen science. Trends Ecol Evol. 2009;24:467-471.

Simion P, Philippe H, Baurain D, Jager M, Richter DJ, Di Franco A, Roure B, Satoh N, Quéinnec E, Ereskovsky A, Lapébie P, Corre E, Delsuc F, King N, Wörheide G, Manuel M. A Large and Consistent Phylogenomic Dataset Supports Sponges as the Sister Group to All Other Animals. Current Biology 2017;27:958-967.

Shiganova TA, Bulgakova YV, Volovik SP, Mirzoyan ZA, Dudkin SI. The new invader Beroe ovata Mayer 1912 and its effect on the ecosystem in the northeastern Black Sea. Hydrobiologia 2001;451:187-197.

Shiganova TA. Invasion of the Black Sea by the ctenophore Mnemiopsis leidyi and recent changes in pelagic community structure. Fish Oceanogr. 1998;7:305-310.

Shiganova T, Malej A. Native and non-native ctenophores in the Gulf of Trieste, Northern Adriatic Sea. J Plankt Res. 2009;1:61-71.

von Byern J, Mills CE, Flammang P. Bonding Tactics in Ctenophores - Morphology and Function of the Colloblast System. In: von Byern J, Grunwald I. (eds) Biological Adhesive Systems. Springer, Vienna. 2010

WoRMS Editorial Board. World Register of Marine Species. 2020;Available from http://www.marinespecies.org at VLIZ. Accessed 2020-08-30. doi:10.14284/170 


\section{Table $\mathbf{1}$ (on next page)}

List of the ctenophore genera that have been described or photographed around South Africa, with an indication of how many species are recorded in each.

Comparative information provided for other coastal regions around the world, based on recent regional treatments that have not been updated since their publication. * known introduction. Source - 1 this study, 2 Deidun (2011), 3 Cinar et al. (2014), 4 Shiganova \& Malej (2009), 5 Ruiz-Escobar et al. (2015), 6 Schiariti et al. (2020), 7 Oliveira et al. (2007), 8 Gershwin et al. (2010), 9 O'Sullivan (1986), 10 Oliveira et al. (2016), 11 Moro et al. (2013). Information on coastline length $(\mathrm{km})$ obtained from https://en.wikipedia.org/wiki/List_of_countries_by_length_of_coastline. 


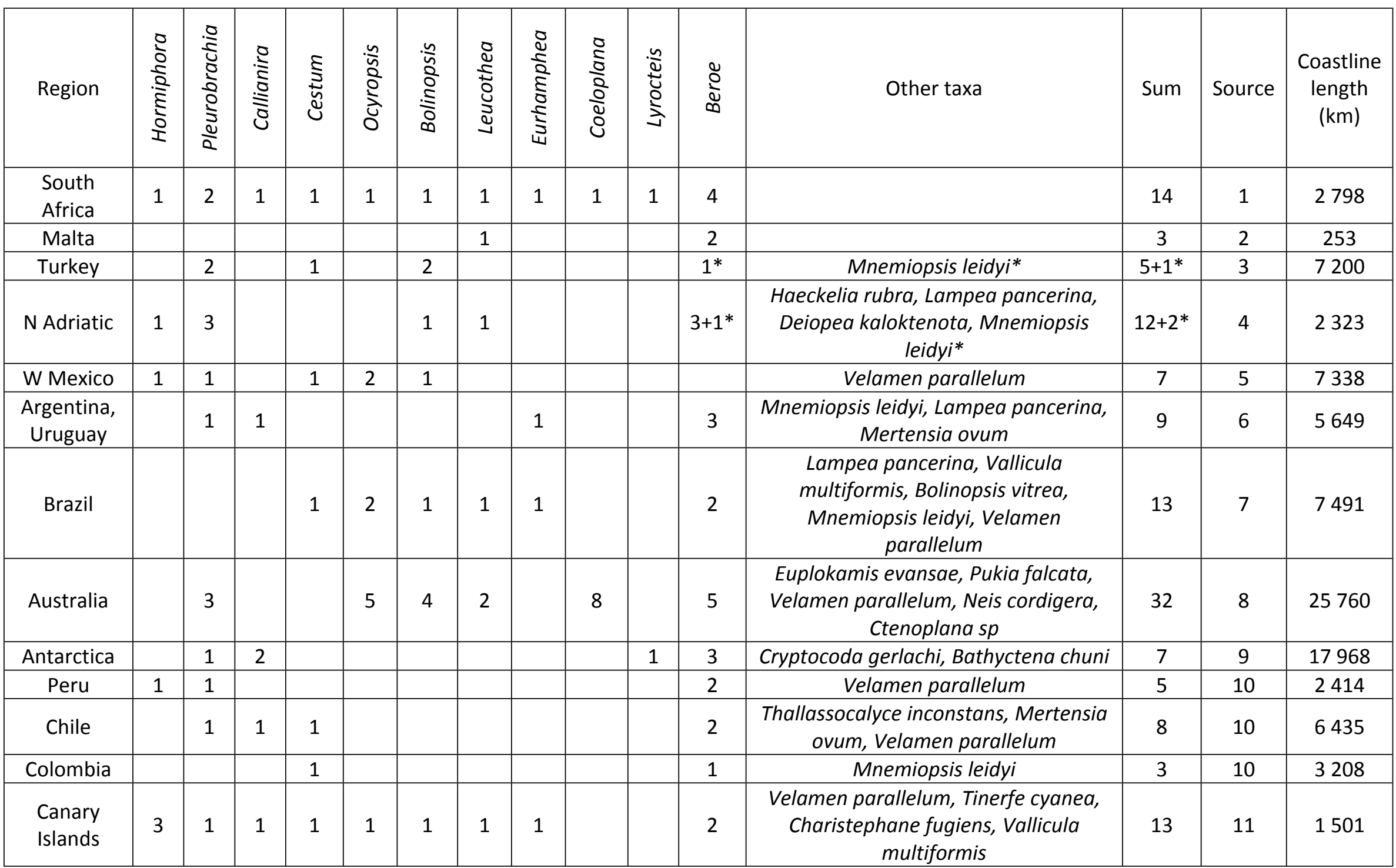




\section{Table 2 (on next page)}

The total number of dives made by Peter Southwood in False Bay and environs over the period $2003-2019$.

The number of separate dives each month in which different ctenophore morphospecies were photographed is also shown (percentage dives in parentheses). 


\begin{tabular}{|c|c|c|c|c|c|c|c|c|c|c|c|c|}
\hline Month & Jan & Feb & Mar & Apr & May & Jun & Jul & Aug & Sep & Oct & Nov & Dec \\
\hline $\begin{array}{c}\text { Total No } \\
\text { Dives }\end{array}$ & 68 & 55 & 58 & 56 & 47 & 52 & 65 & 43 & 55 & 51 & 65 & 96 \\
\hline Pleurobrachia & $\begin{array}{c}1 \\
(1.5)\end{array}$ & $2(3.6)$ & & $\begin{array}{c}1 \\
(1.8)\end{array}$ & $1(2.1)$ & & $\begin{array}{c}1 \\
(1.5)\end{array}$ & & & & & \\
\hline Hormiphora & & & $\begin{array}{c}1 \\
(1.7) \\
\end{array}$ & & & & & & & $1(2)$ & & \\
\hline Cestum & & & & & & & & & & & $\begin{array}{c}1 \\
(1.5)\end{array}$ & \\
\hline Ocyropsis & & & & $\begin{array}{c}2 \\
(3.6)\end{array}$ & $\begin{array}{c}5 \\
(10.6)\end{array}$ & $\begin{array}{c}3 \\
(5.8)\end{array}$ & & & & & & \\
\hline Leucothea & & & & & $1(2.1)$ & $\begin{array}{c}4 \\
(7.7)\end{array}$ & $\begin{array}{c}1 \\
(1.5)\end{array}$ & $\begin{array}{c}2 \\
(4.7)\end{array}$ & $\begin{array}{c}2 \\
(3.6)\end{array}$ & & & \\
\hline Bolinopsis & & & $\begin{array}{c}3 \\
(5.2)\end{array}$ & $\begin{array}{c}2 \\
(3.6)\end{array}$ & $3(6.4)$ & $\begin{array}{c}2 \\
(3.8)\end{array}$ & $\begin{array}{c}5 \\
(7.7)\end{array}$ & & $\begin{array}{c}1 \\
(1.8)\end{array}$ & & & \\
\hline Beroe & $\begin{array}{c}6 \\
(8.8)\end{array}$ & $\begin{array}{c}8 \\
(14.5)\end{array}$ & $\begin{array}{c}3 \\
(5.2)\end{array}$ & $\begin{array}{c}2 \\
(3.6)\end{array}$ & $2(4.3)$ & & $\begin{array}{c}5 \\
(7.7)\end{array}$ & $\begin{array}{c}1 \\
(2.3)\end{array}$ & $\begin{array}{c}3 \\
(5.5)\end{array}$ & $\begin{array}{c}2 \\
(3.9)\end{array}$ & $\begin{array}{c}1 \\
(1.5)\end{array}$ & $\begin{array}{c}3 \\
(3.1)\end{array}$ \\
\hline
\end{tabular}

1

2 Table 2: 
Figure 1

Satellite image (4-km resolution MODIS Aqua day-time SST) of the southern African subregion showing average sea surface temperatures for 2008.

Adapted from Gibbons et al. (2010b).

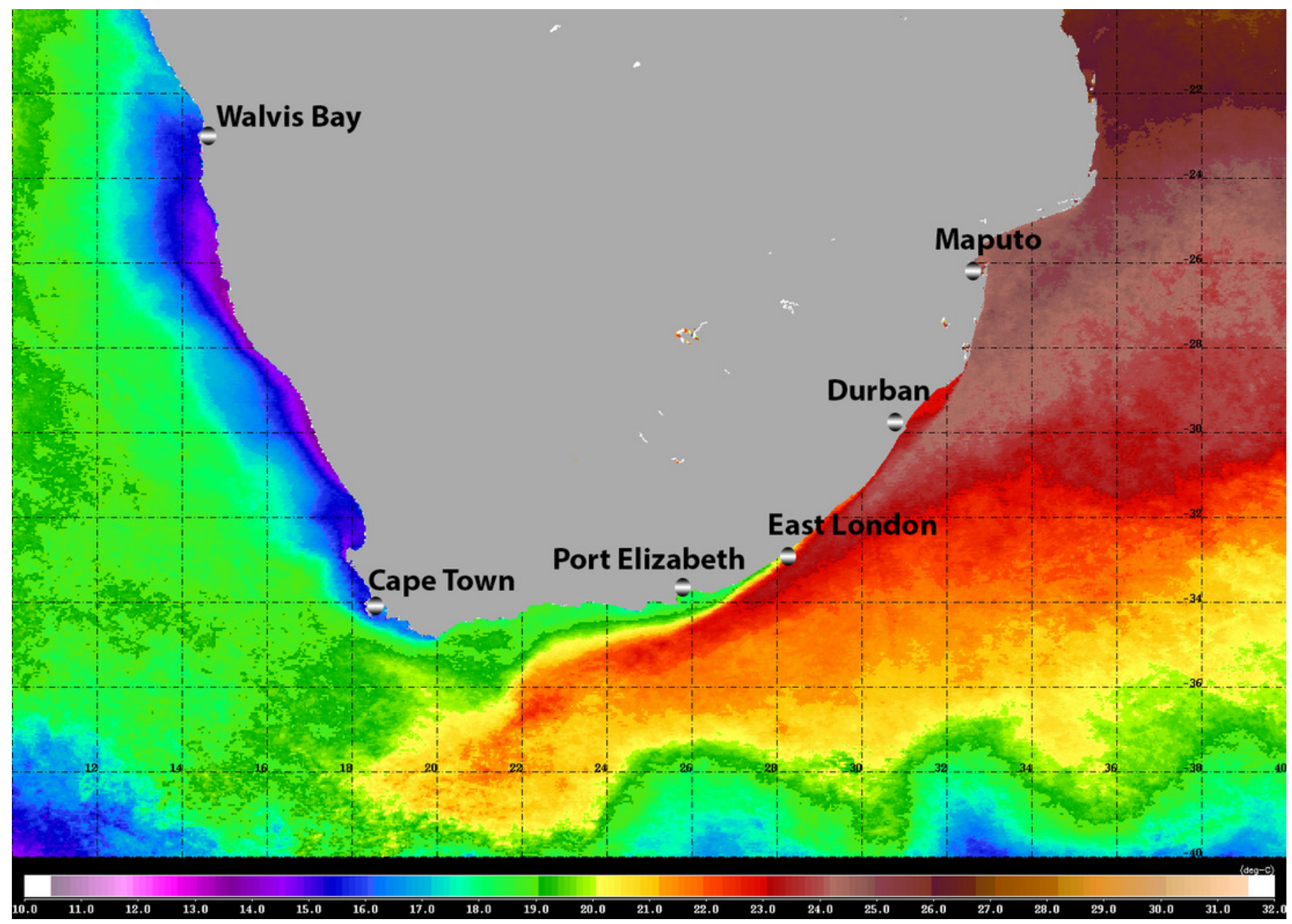




\section{Figure 2}

An aggregation of Leucothea sp. off southern Mozambique: arrows indicate specimens of Cestum veneris.

Photograph provided by Jenny Stromvoll.

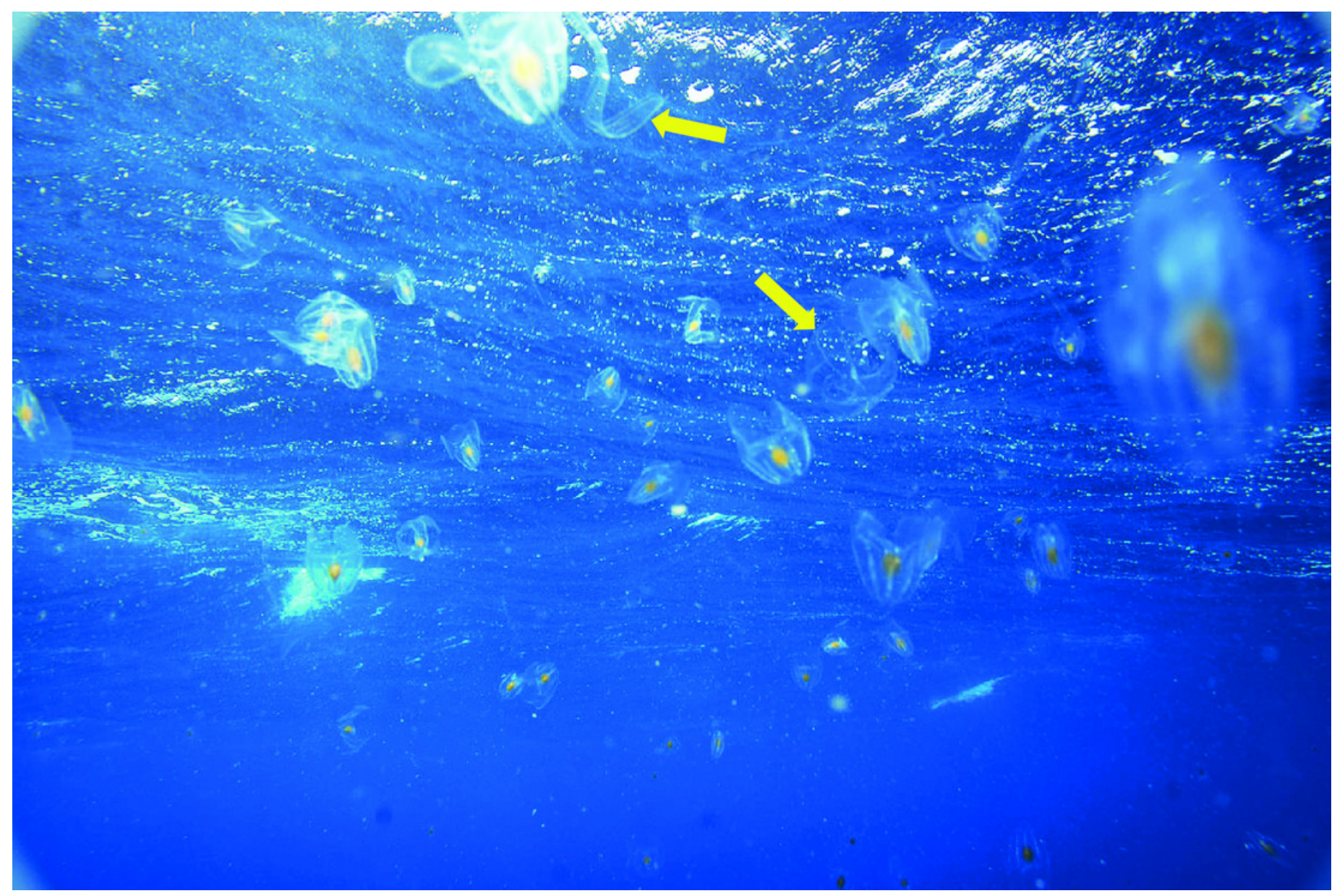




\section{Figure 3}

Symmetry planes of a ctenophore, using Bolinopsis vitrea as model.

(A) view of the tentacular plane; (B) aboral view, showing the stomodaeal axis (in blue) and the tentacular axis (in yellow); and (C) view of the stomodaeal plane. (photos: A. Migotto) Reproduced with permission of O. Oliveira; adapted from Oliveira et al. (2007).
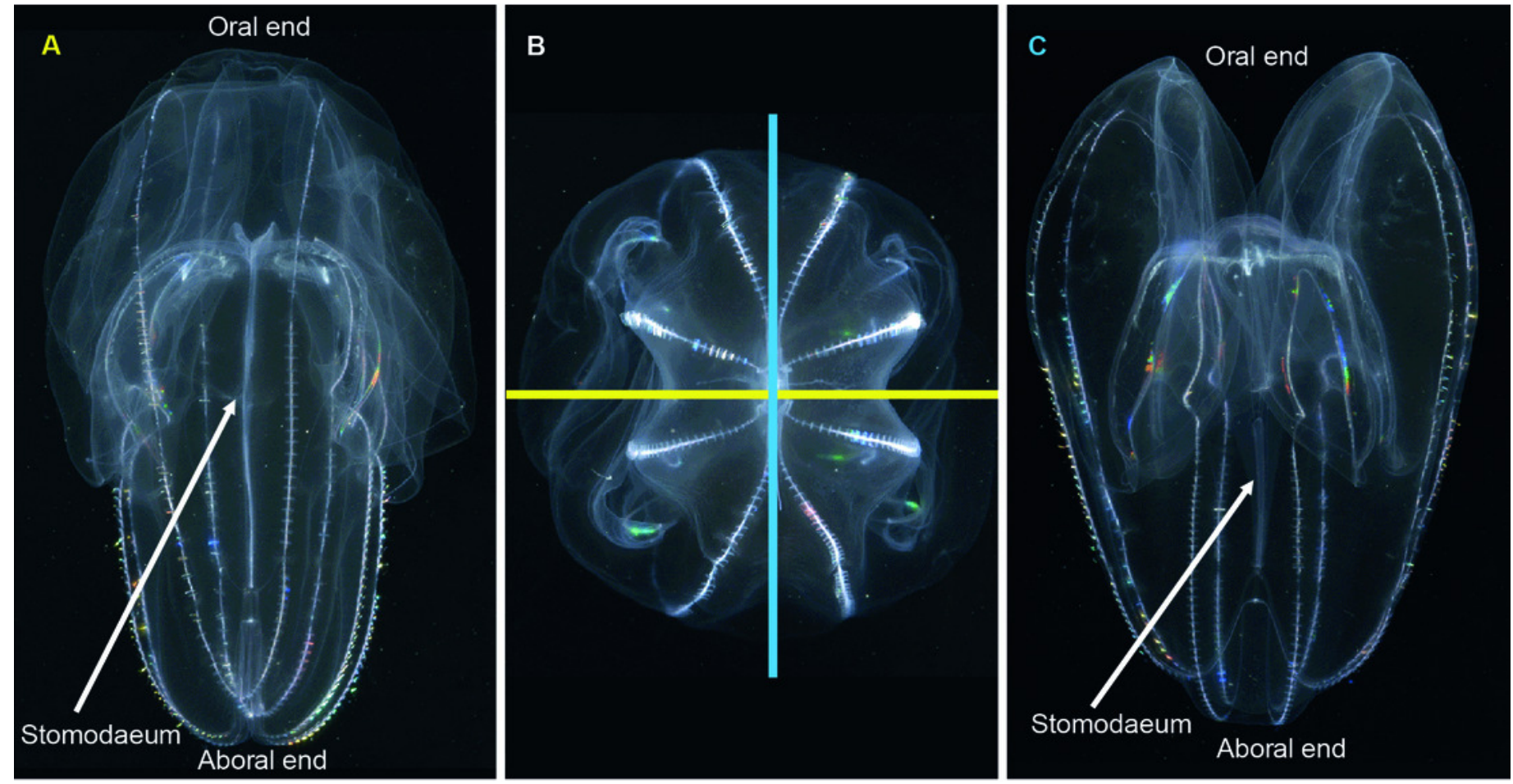


\section{Figure 4}

Basic ctenophore anatomy, (A) Pleurobrachia pileus, in stomodaeal plane, as an example of a cydippid ctenophore; (B) Mnemiopsis leidyi, in stomodaeal plane, as an example of a lobate ctenophore.

(A) photograph by Kåre Telnes, http://www.seawater.no/fauna/ctenophora/pileus.html, (B) photograph by Bruno C. Vellutini, CC BY-SA 3.0, https://commons. wikimedia.org/w/index.php?curid=30155106

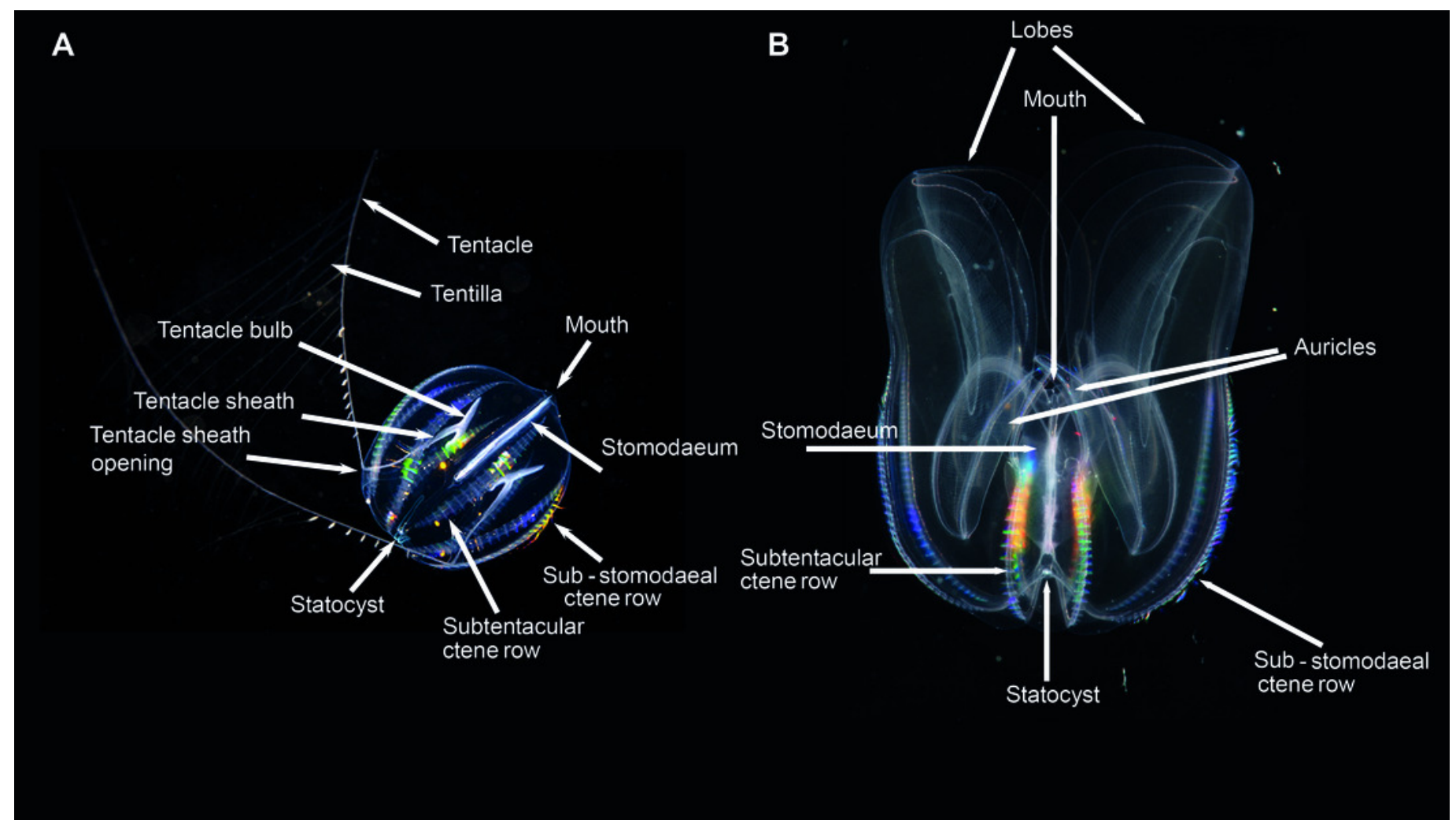




\section{Figure 5}

Differences in overall body shape of the cydippid ctenophores Hormiphora sp. (A, C) and Pleurobrachia sp. (B, D).

Photographs provided by: (A, B) Guido Zsilavecz, (C) Georgina Jones, (D) Craig Foster; taken at Oudekraal (A, B) along the west coast of the Cape Peninsula, (C) in Sodwana Bay in northern KwaZulu Natal and (D) in False Bay. Note the hyperiid amphipod associated with Hormiphora sp. (A); such parasitic associations with ctenophores are not uncommon. 

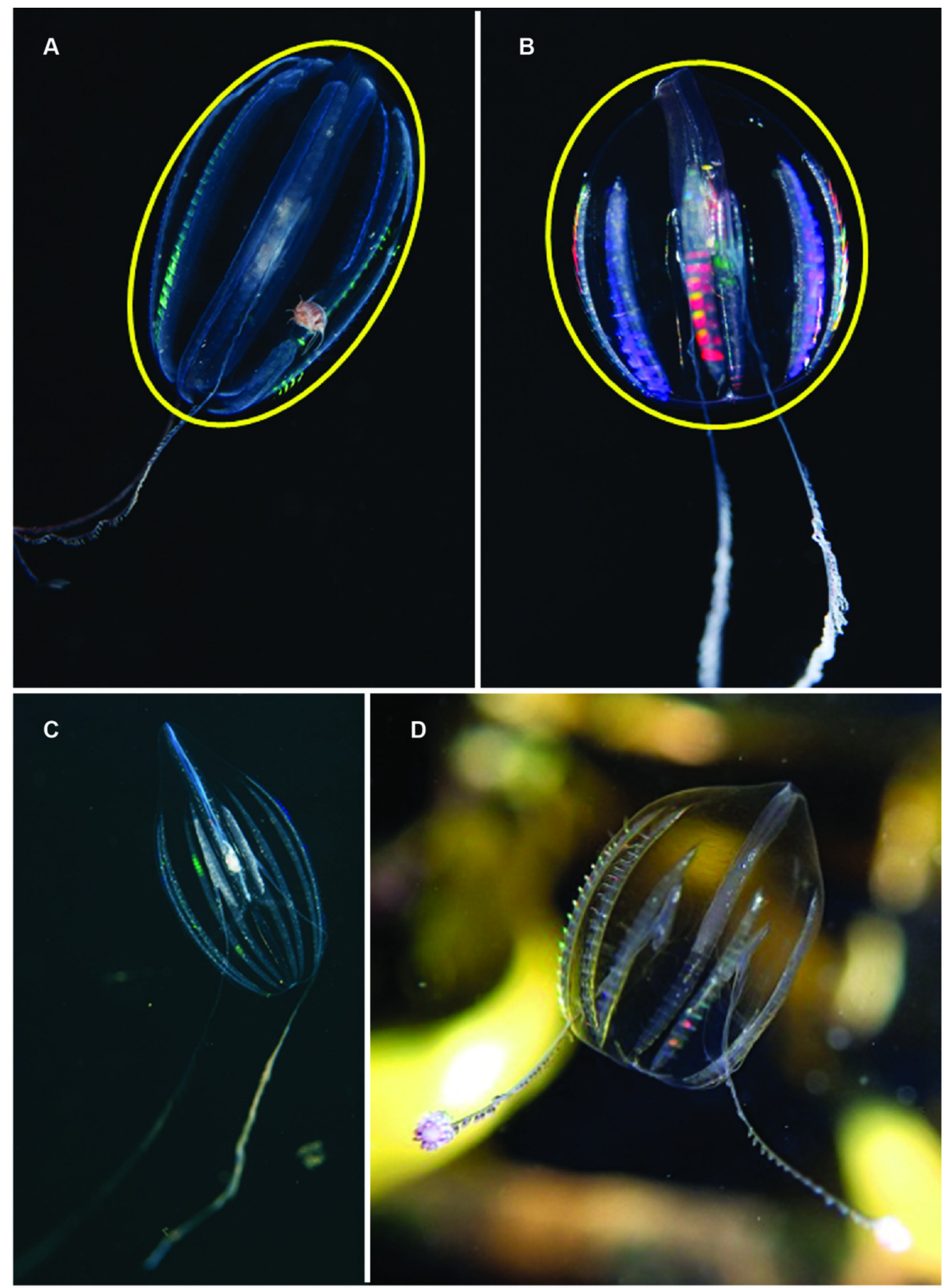

Peer] reviewing PDF | (2020:09:52529:1:1:NEW 5 Dec 2020) 


\section{Figure 6}

Cestum veneris, also known as the Venus girdle.

This strap-like ctenophore is characterised by ctene rows (arrows, B) that run along the aboral surfaces and tentacles that run along the oral edges, with tentillae that drape across the body (faintly visible in B and C). A knowledge of the origins (encircled, D) of the lateral canals (arrows, D) is important in distinguishing this species from Velamen parallelum. Photographs provided by: (A) Mike and Val Fraser, (B) Jenny Stromvoll, (C) Georgina Jones, (D) Craig Foster; (A - C) in southern Mozambique and (D) in False Bay. Note the hyperiid amphipod (Streetsia sp) in (B, C) and what looks like a juvenile euphausiid in the stomodeum (dashed arrow, C).
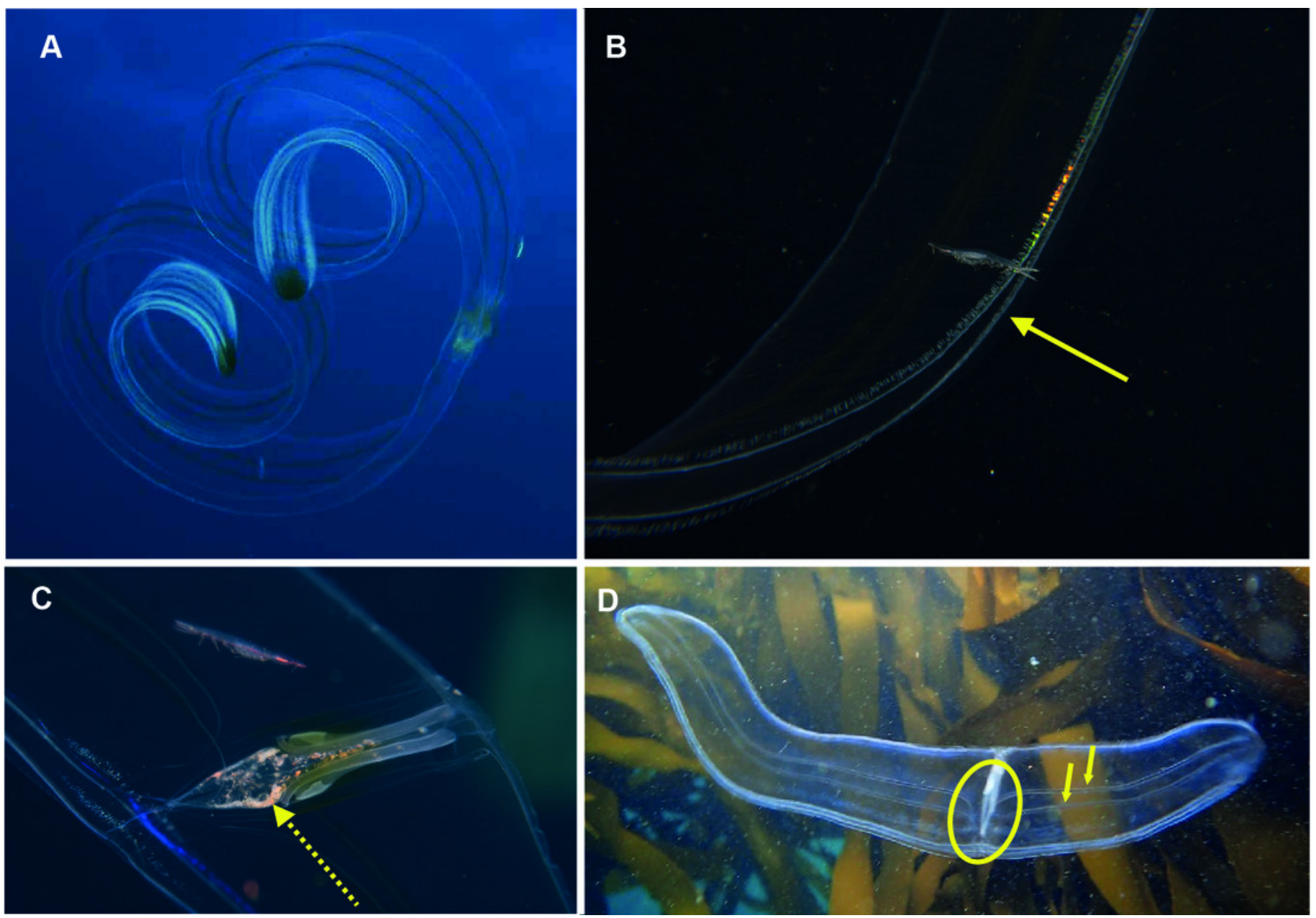


\section{Figure 7}

Ocyropsis sp (A, C), Ocyropsis maculata? (B), illustrating its "cupped-hands" appearance.

Note the pigmented spots at the base of the lobes of $O$. maculata?. Arrows highlight the auricles (a) and black spot (b). Photographs provided by: (A) Craig Foster, (B) Jenny Stromvoll, (C) Peter Southwood; taken in False Bay (A, C), and southern Mozambique (B).
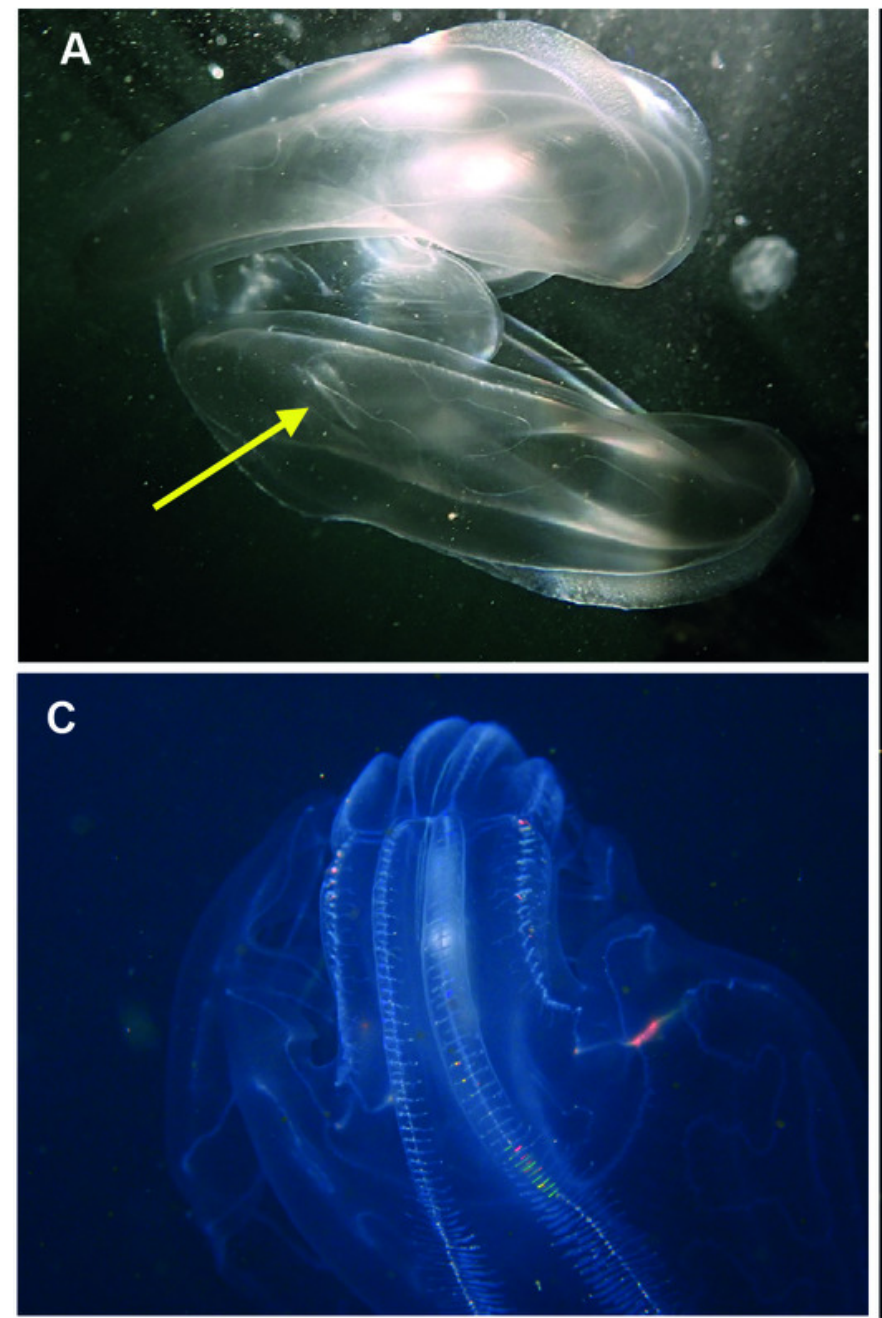


\section{Figure 8}

Bolinopsis sp.

Photographs provided by: (A, C) Peter Southwood, (B) Craig Foster; all taken in False Bay.
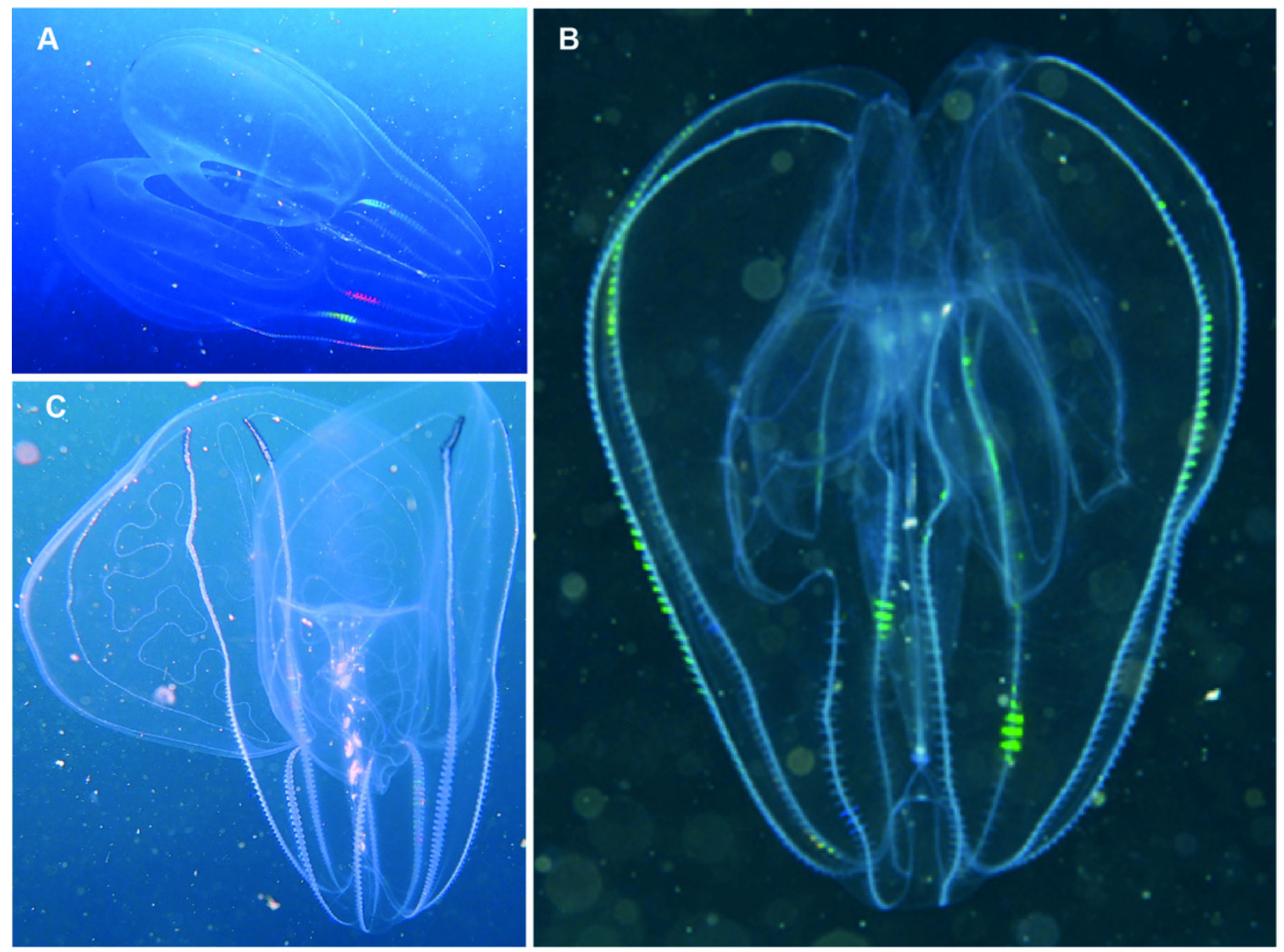
Figure 9

Leucothea sp., which is characterised by the presence of numerous papillae covering the relatively long body.

Solid arrows highlight the long auricles and dashed arrows indicate the long trailing

tentacles. Photographs provided by: (A, B) Craig Foster, (C) Jenny Stromvoll; (A, B) taken in False Bay, (C) in southern Mozambique. 

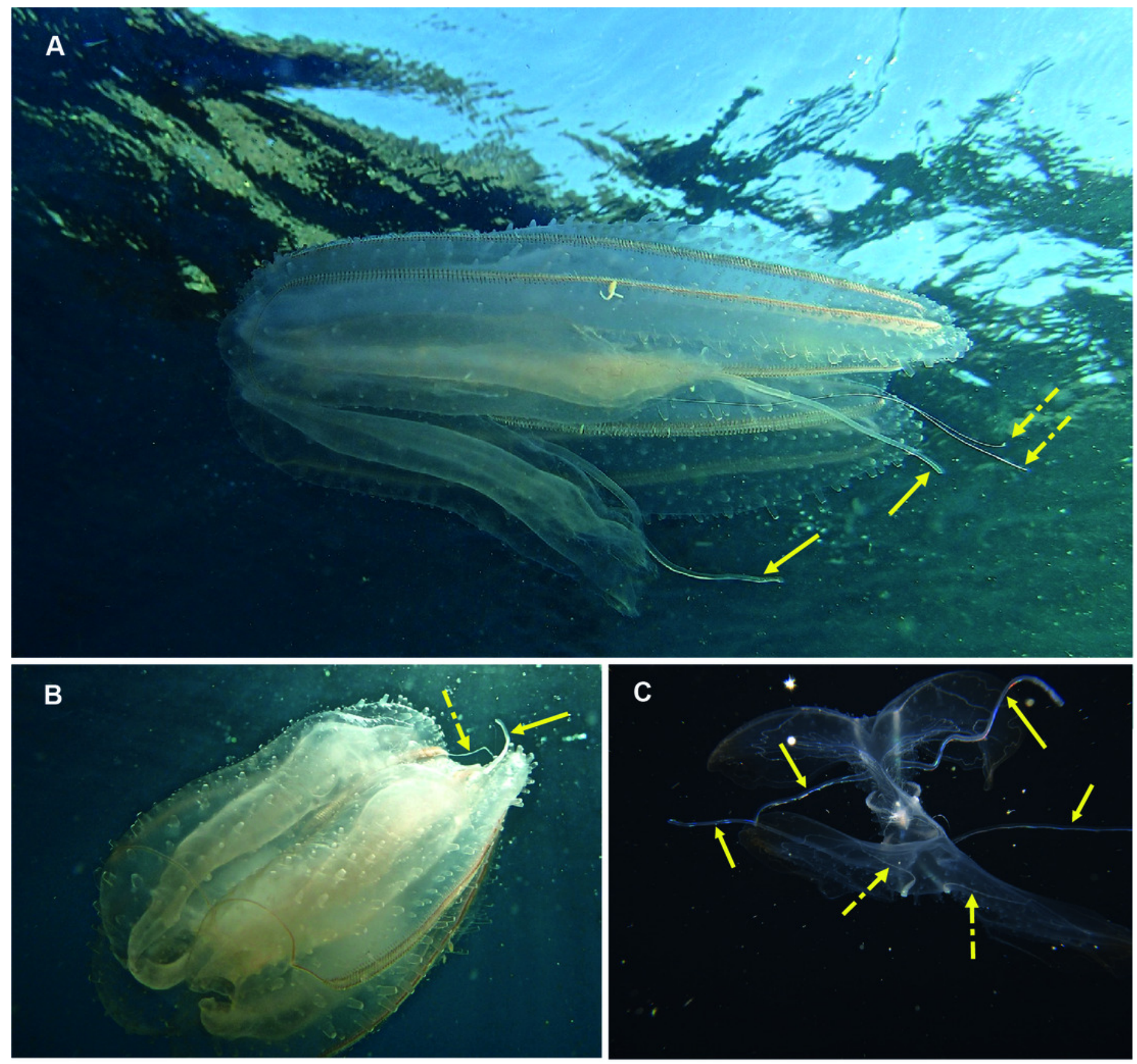


\section{Figure 10}

\section{Eurhamphea sp.}

An uncommon lobate ctenophore that is characterised by its short oral lobes (arrows, A), aboral projections that each terminate in a simple filament (arrows, B) and prominent "ink" spots. Photographs provided by Jenny Stromvoll; both taken of the same specimen in southern Mozambique.
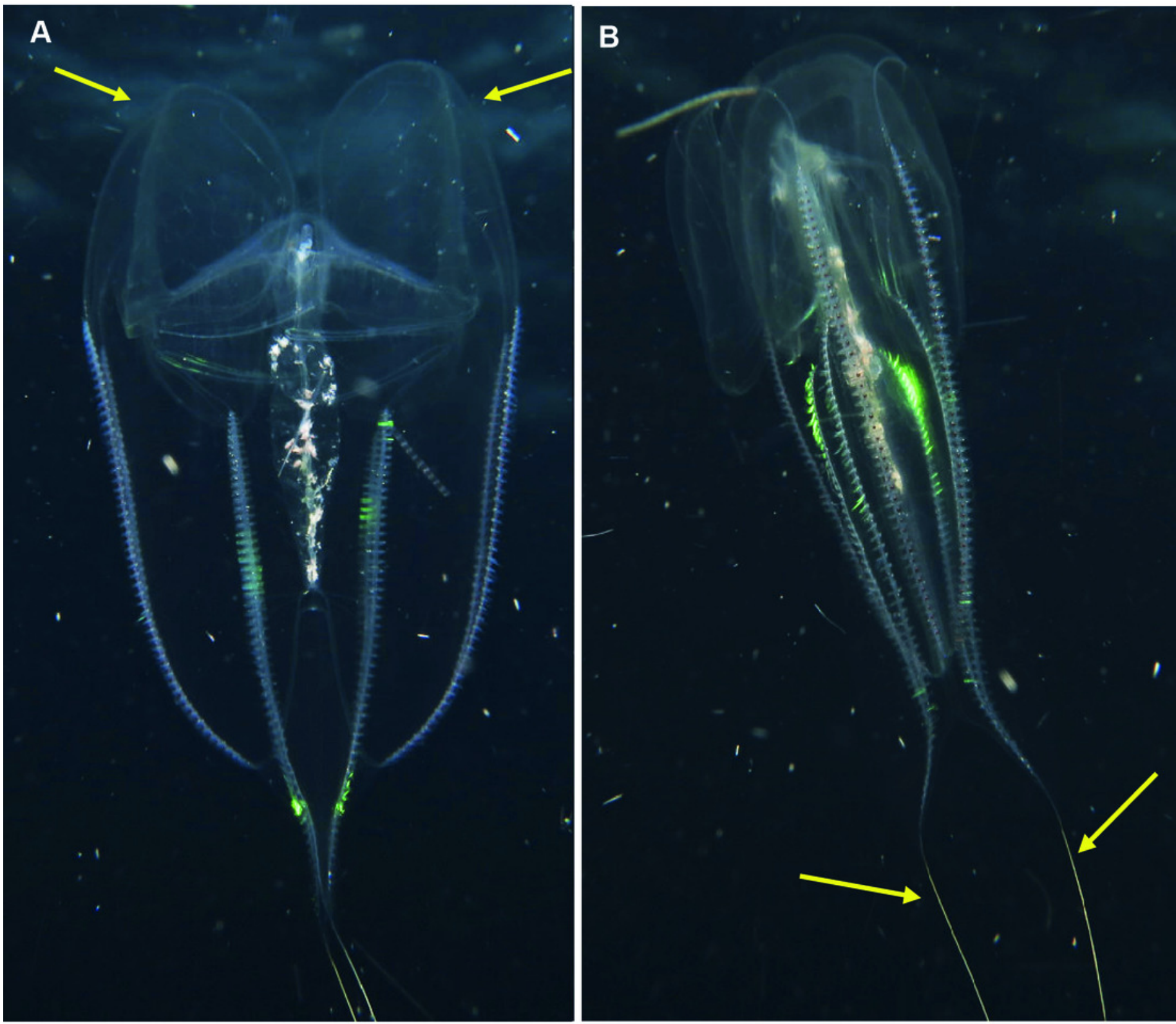


\section{Figure 11}

Coeloplana sp. Cryptic species of benthic ctenophores that lack ctene rows but possess tentacles (arrows).

A knowledge of the species on which specimens of Coeloplana are found can assist in

identification. Photographs provided by: Georgina Jones; (A, B) taken in False Bay, (C, D) from southern Mozambique. 


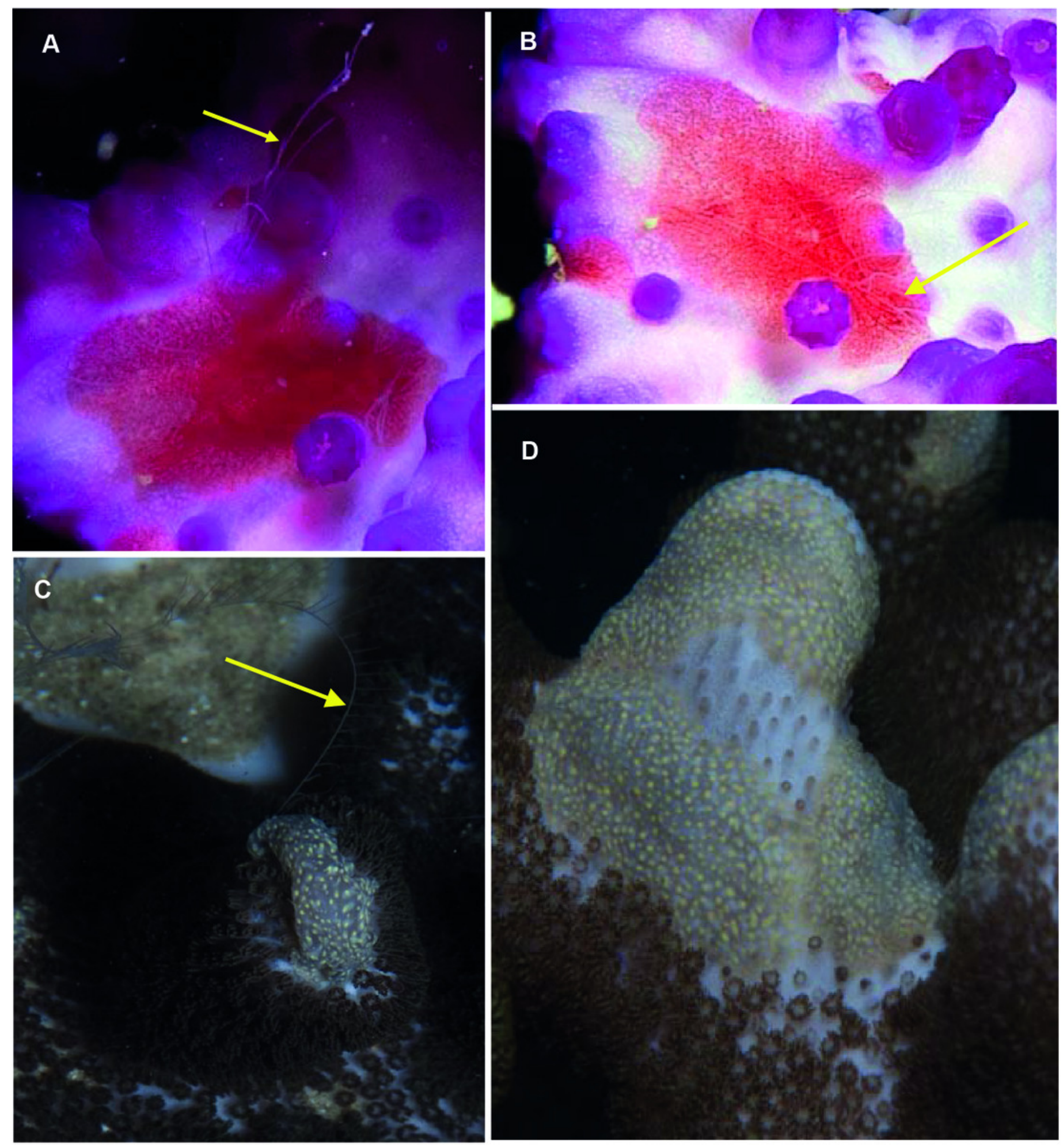




\section{Figure 12}

Lyrocteis sp. A lyre-shaped species of benthic ctenophore, without ctene rows as adult and with two tentacles (one indicated by arrow, C) that emerge from each of the two finger-like projections.

All specimens were photographed at depths of about $70 \mathrm{~m}$ using a remotely operated vehicle in the canyons of Sodwana Bay and ISimangaliso Wetland Park. Photographs provided by Ryan Palmer, using the research platform of the South African Institute of Aquatic Biodiversity (SAIAB) to the ACEP Surrogacy project, the ACEP Canyon Connections project, the ACEP Spatial Solutions project and the ACEP Protea Canyon project. ACEP Surrogacy project, the ACEP Canyon Connections project, the ACEP Spatial Solutions project and the ACEP Protea Canyon project. 

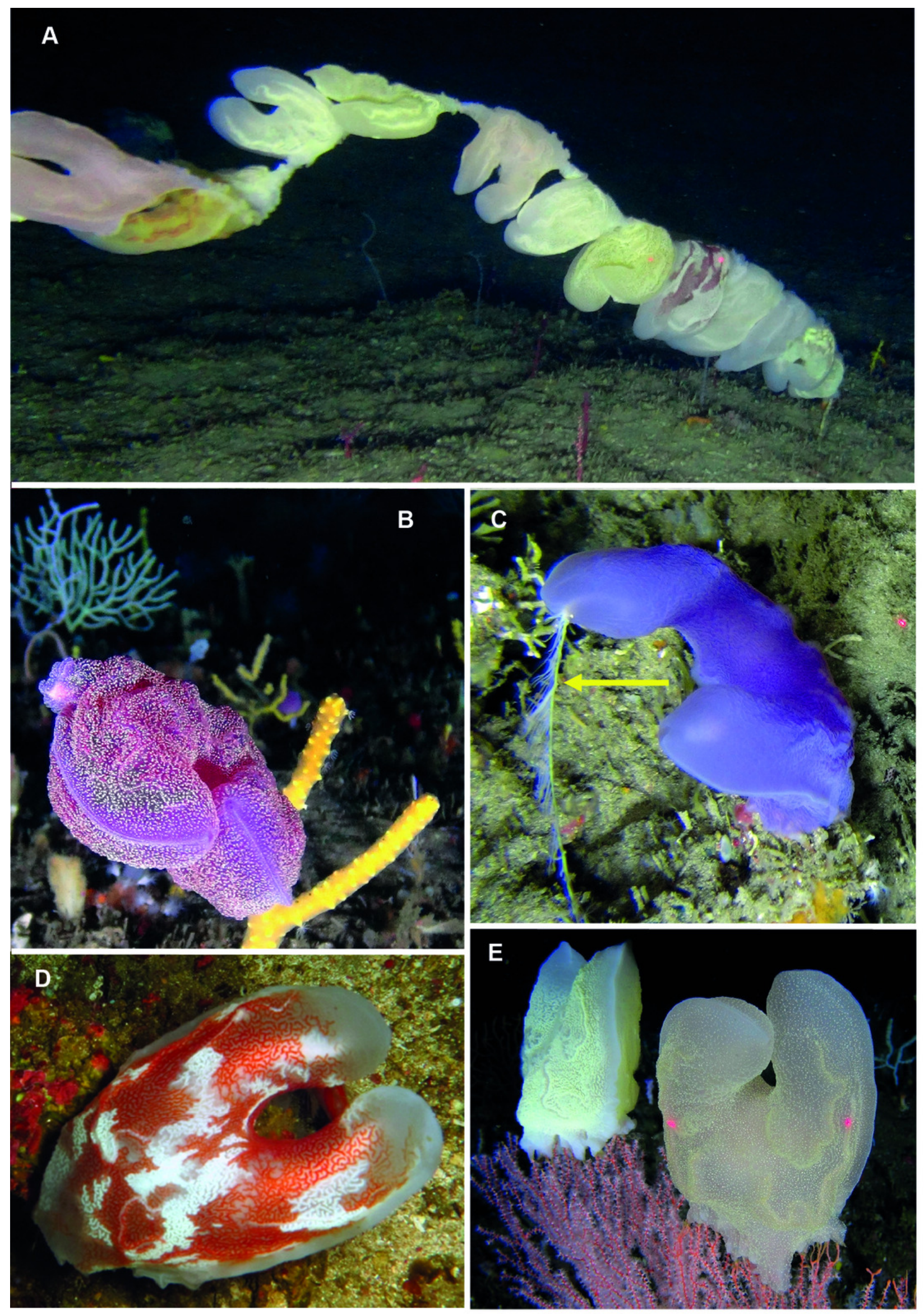


\section{Figure 13}

Beroe sp. (A - C), Beroe forskalii? (D) and Beroe mitrata? (E).

Species of Beroe lack tentacles and usually resemble cigars; the network of canals (C) in the body wall helps to separate the different species. Beroe forskalii? may be pink in colour and is markedly broader at the oral end. Photographs provided by: (A, D) Craig Foster, (B) Guido Zsilavecz, (C) Jenny Stromvoll, (E) Georgina Jones; (A, D) taken in False Bay, (B) at Oudekraal, and $(\mathrm{C}, \mathrm{E})$ in southern Mozambique. 

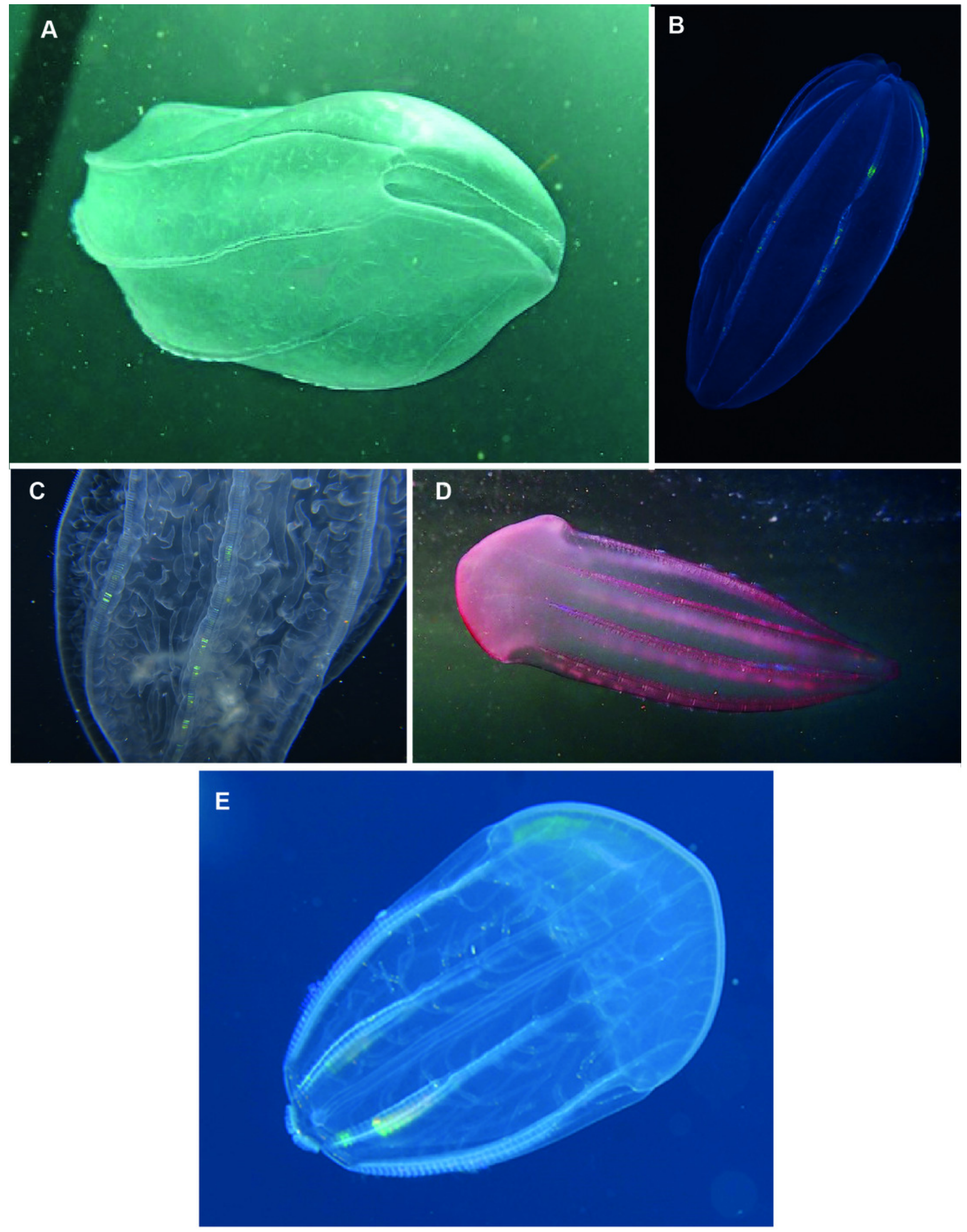